\title{
WATER, ICE, AND METEOROLOGICAL MEASUREMENTS AT SOUTH CASCADE GLACIER, WASHINGTON, 1997 BALANCE YEAR
}

Water-Resources Investigations Report 98-4090
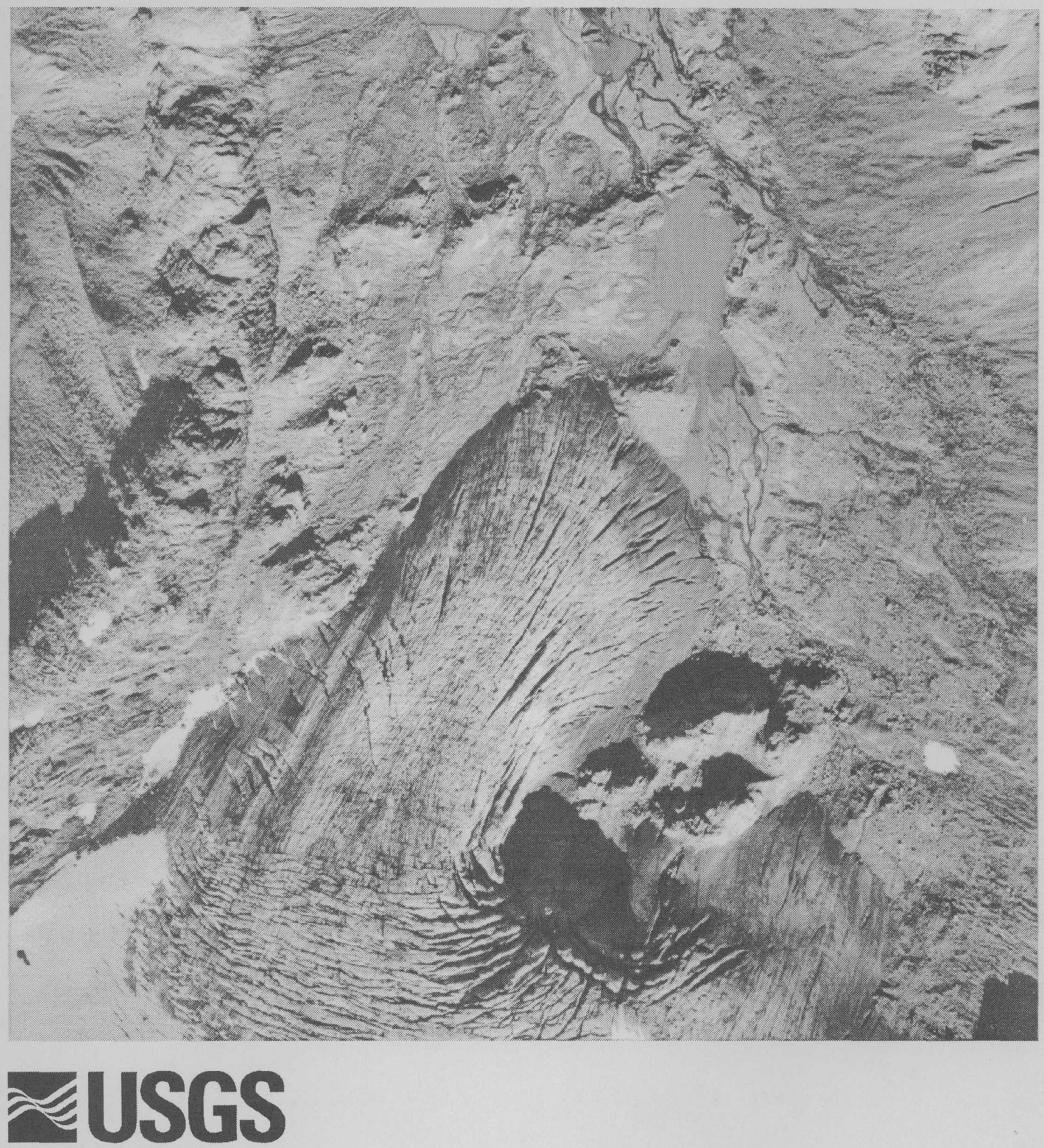
Cover - South Cascade Glacier, September 23, 1997. 


\section{WATER, ICE, AND METEOROLOGICAL MEASUREMENTS AT SOUTH CASCADE GLACIER, WASHINGTON, 1997 BALANCE YEAR \\ By Robert M. Krimmel}

U.S. GEOLOGICAL SURVEY

Water-Resources Investigations Report 98-4090 


\section{U.S. DEPARTMENT OF THE INTERIOR}

BRUCE BABBITT, Secretary

U.S. GEOLOGICAL SURVEY

Thomas J. Casadevall, Acting Director

For additional information write to:

Ice and Climate Project

U.S. Geological Survey

University of Puget Sound

Tacoma, Washington 98416
Copies of this report can

be purchased from:

U.S. Geological Survey

Branch of Information Services

Box 25286

Denver Federal Center

Denver, Colorado 80225 


\section{CONTENTS}

Abstract

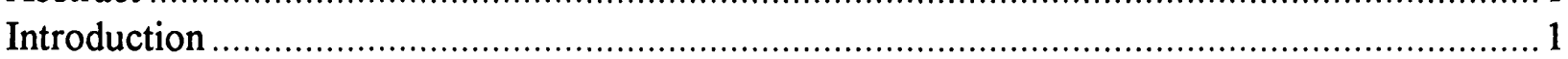

Description and climate of the area ....................................................................... 2

Measurement systems ......................................................................................... 2

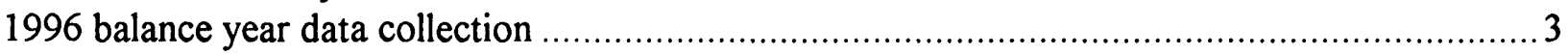

Recorded variables..................................................................................... 3

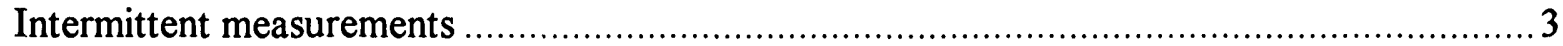

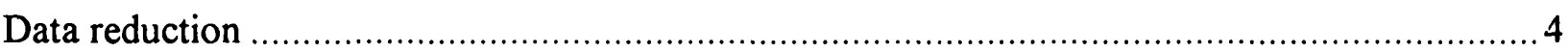

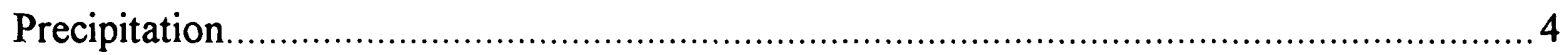

Salix Creek runoff .......................................................................................... 5

South Fork Cascade River runoff .......................................................................... 5

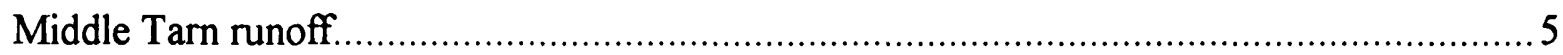

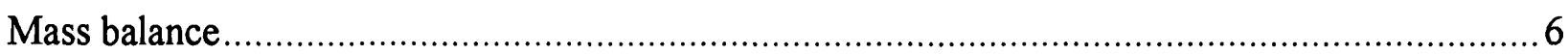

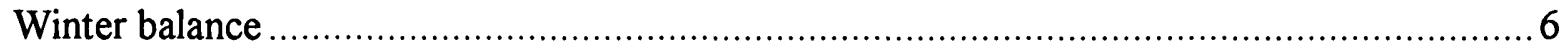

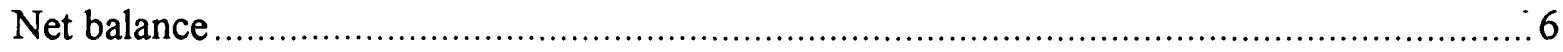

Balance year to water year adjustments .............................................................. 7

Balance measurement errors.......................................................................... 7

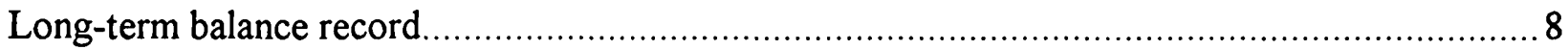

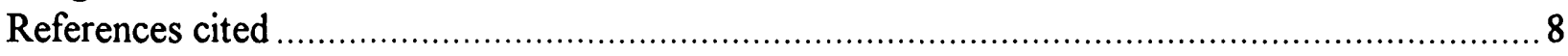

\section{ILLUSTRATIONS}

Figure 1. Map showing South Cascade Glacier and vicinity ........................................... 10

2. Graph showing air temperature near South Cascade Glacier during the

1997 water year ...................................................................... 11

3. Graph showing instantaneous water stages and hourly precipitation near

South Cascade Glacier during the 1997 water year..................................... 12

4. Map showing snow depths on South Cascade Glacier on May 9, 1997 .................. 13

5. Graph showing snow depth and firn or ice loss at South Cascade Glacier at each 1997 stake ..................................................................... 14

6. Vertical photograph of South Cascade Glacier, September 23, 1997 ..................... 15

7. Map showing altitude grid for South Cascade Glacier, September 23, $1997 \ldots \ldots \ldots \ldots .16$

8. Map showing South Cascade Glacier terminus positions,

September 10, 1996 and September 23, 1997............................................ 17

9. Graphs showing daily runoff and precipitation near South Cascade

Glacier during the 1997 water year ........................................................ 18

10. Graph showing snow depth as a function of altitude at South Cascade

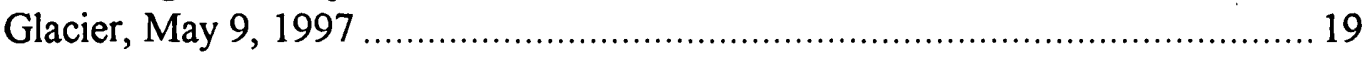

11. Graph showing net balance as a function of altitude at South Cascade

Glacier, 1997 


\section{TABLES}

Page

Table 1. Air temperature at 1,587 meters altitude, Salix Creek Basin, 1997 water year ............20

2. Air temperature at 1,631 meters altitude, South Cascade Glacier Basin,

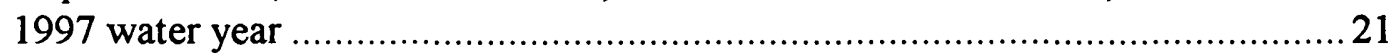

3. Air temperature at 1,848 meters altitude, South Cascade Glacier Basin,

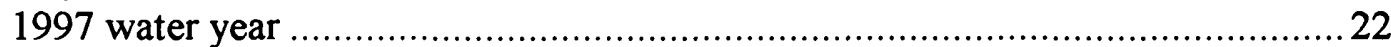

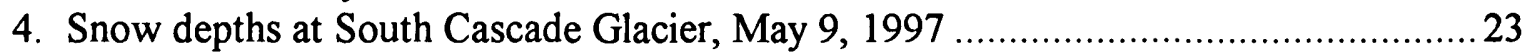

5. Snow density at South Cascade Glacier, May 9, 1997......................................... 23

6. Stake and late season core measurements at South Cascade Glacier

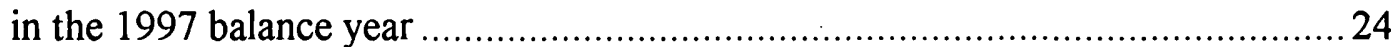

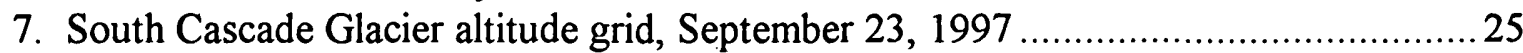

8. Precipitation (gage catch) at 1,587 meters altitude, Salix Creek Basin,

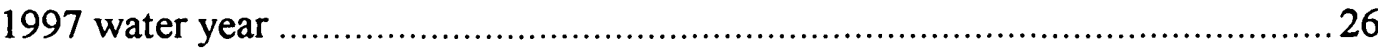

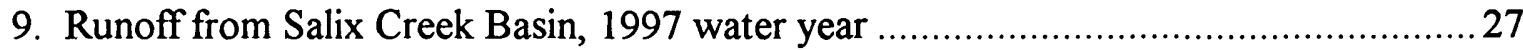

10. Runoff from South Fork Cascade River Basin, 1997 water year.................................27

11. Runoff from Middle Tarn Basin, 1997 water year ................................................... 28

12. Values used to interpolate snow depth at any altitude on South Cascade Glacier, 1997

13. Values used to interpolate net balance at any altitude on South Cascade Glacier, 1997 29

14. Mass balance time series at South Cascade Glacier 30 


\section{CONVERSION FACTORS, VERTICAL DATUM, SYMBOLS, AND MACHINE-READABLE FILES}

\begin{tabular}{lcl} 
Multiply & By & To obtain \\
\hline degree Celsius $\left({ }^{\circ} \mathrm{C}\right)$ & 1.8, then add 32 & degree Fahrenheit \\
kilogram & 2.205 & pound \\
kilogram per cubic meter $\left(\mathrm{kg} / \mathrm{m}^{3}\right)$ & 0.06243 & pound per cubic foot \\
kilometer $(\mathrm{km})$ & 0.6214 & mile \\
meter $(\mathrm{m})$ & 3.281 & foot \\
millimeter $(\mathrm{mm})$ & 0.03937 & inch \\
square kilometer $\left(\mathrm{km}^{2}\right)$ & 0.3861 & square mile \\
\hline
\end{tabular}

\section{Vertical datum:}

In this report "sea level" refers to the National Geodetic Vertical Datum of 1929 (NGVD of 1929)--a geodetic datum derived from a general adjustment of the first-order level nets of both the United States and Canada, formerly called Sea Level Datum of 1929.

Symbols used in this report:
$\bar{b}_{0}$
The change in balance between the minimum balance near the beginning of the water year and October 1.
$\bar{b}_{1}$ The change in balance between the minimum balance near the end of the water year and September 30.
$\bar{b}_{\mathrm{a}}$ The change in snow, firn, and ice storage between the beginning and end of some fixed period, which here is the water year.
$\bar{b}_{\mathrm{m}}(\mathrm{s})$ The snow above the previously formed summer surface as measured directly by
$\bar{b}_{\mathrm{n}}$ field work in late spring as near as possible to the time of greatest glacier mass. The change in snow, firn, and ice storage between times of minimum mass.
$\bar{b}_{\mathrm{x}}(\mathrm{s})$ The maximum of snow mass during the balance year.
$\mathrm{q}$ River discharge.
$\mathrm{S} \quad$ River stage.
$\mathrm{X} \quad$ Approximate east/west position in the local survey net.
Y Approximate north/south position in the local survey net.
Z Altitude above NGVD of 1929.

Machine-readable files:

Most of the data contained in this report have been recorded on easily copied computer media. This machine-readable material is available from the World Data Center, Campus Box 449, University of Colorado, Boulder, CO $80309<\mathrm{URL}$ : http://www-nsidc.colorado.edu/NOAA/>. 



\title{
WATER, ICE, AND METEOROLOGICAL MEASUREMENTS AT SOUTH CASCADE GLACIER, WASHINGTON, 1997 BALANCE YEAR
}

\author{
Robert M. Krimmel
}

\begin{abstract}
Winter snow accumulation and summer snow, firn, and ice melt were measured at South Cascade Glacier, Washington to determine the winter and net balances for the 1997 balance year. The 1997 winter balance, averaged over the glacier, was 3.71 meters, and the net balance was 0.63 meter. The winter balance was the greatest since 1972 (4.27 meters), and the second largest since the record began in 1959. The net balance, which was positive for the second year in a row, was 1.57 meters greater than the 1977-96 average (-0.94 meter). Runoff was measured from the glacier and an adjacent non-glacierized basin. Air temperature and precipitation were measured nearby. This report makes these data available to the glaciological and climatological community.
\end{abstract}

\section{INTRODUCTION}

South Cascade Glacier is a small valley glacier near the crest of the North Cascade Range, Washington State (fig. 1). Numerous variables relating to the glacier regime have been measured on and near South Cascade Glacier since the late 1950's. The long-term goal of this project is to understand the climate-glacier relation. A short-term goal is to document the measurements with sufficient detail so that an internally consistent record of conditions on and around the glacier can be assembled despite personnel changes, discontinuous records, and changing methods of data collection and analysis. Some periods of record at South Cascade Glacier have been documented. Work from 1957-64 is described by Meier and Tangborn (1965), work from 1965-67 is described by Meier and others (1971) and by Tangborn and others (1977). Hydrologic and meteorological data for 1957-67 are presented by Sullivan (1994). Mass balance results for 1958-85 are summarized by Krimmel (1989), and are presented in detail for 1992-96 (Krimmel, 1993, 1994, 1995, 1996a, 1997). The purpose of this report is to document the measurements of the 1997 balance year that are relevant to the relation between South Cascade Glacier and climate. These measurements include those of basin runoff, precipitation, air temperature, snow thickness and density, ice ablation, and surface altitude.

The mass balance program at South Cascade Glacier is part of a larger U.S. Geological Survey effort to monitor glacier mass balance throughout the western states. Mass balance at two other glaciers, Gulkana Glacier and Wolverine Glacier, both in Alaska, is also monitored by the USGS. The broad USGS glacier monitoring program is discussed in a separate document (Fountain and others, 1997), and South Cascade Glacier is considered to be a "benchmark glacier" as described in that document. 


\section{Description and Climate of the Area}

South Cascade Glacier is located at the head of the South Fork of the Cascade River, a tributary to the Skagit River, which flows into Puget Sound about $100 \mathrm{~km}$ to the west. The region is dominated by steep terrain, with local relief of more than $1,000 \mathrm{~m}$. Areas within the basin not covered by glacier ice or water are underlain by bedrock. The bedrock is mantled either by a thin layer of soil and, in places, by scrub conifer, heather, or other vegetation typical of the high North Cascade Range, or is covered by glacial moraine or outwash material.

South Cascade Lake Basin has an area ${ }^{1}$ of $6.14 \mathrm{~km}^{2}$, and spans from 1,615 to $2,518 \mathrm{~m}$ altitude. A sub-basin of the South Cascade Lake Basin is the $4.46-\mathrm{km}^{2}$ Middle Tarn Basin ${ }^{2}$, which constitutes the southern two-thirds of the South Cascade Lake Basin. Virtually all icemelt ${ }^{3}$ within the South Cascade Lake Basin takes place in the Middle Tarn Basin.

Salix Creek Basin (fig. 1) is an unglacierized basin adjacent to the South Cascade Lake Basin. It has an area ${ }^{4}$ of $0.22 \mathrm{~km}^{2}$, spans from 1,587 to 2,140 m altitude, and is predominantly south facing.

The climate of the region is maritime. Near the glacier, typical winter low temperatures are about $-10^{\circ} \mathrm{C}$, and typical summer high temperatures are about $20^{\circ} \mathrm{C}$. Most of the precipitation, which commonly amounts to $4.5 \mathrm{~m}$ annually (Meier and others, 1971), falls as snow in the period October to May.

\section{Measurement Systems}

Glacier mass balance definitions (Mayo and others, 1972) are adhered to in this report, and the stratigraphic system, which is more field compatible than the fixed date system, is usually used. The specific terms are defined where first used. Other mass balance nomenclatures are in use, notably those described by Østrem and Brugman (1991), which could as well be used to report these results. The definitions by Mayo and others (1972) are used to maintain consistency with earlier reports on South Cascade Glacier work.

The balance year, defined by Mayo and others (1972) as the interval between the minimum glacier mass in one year and the minimum glacier mass the following year, is used in this report because most of the field measurements reference the surface formed at the end of the previous balance year.

All local geodetic coordinates are in meters, in which the local $+Y$ axis is approximately true north. Vertical locations are in meters above the National Geodetic Vertical Datum of 1929. Horizontal locations are defined by a local system that can be converted to Universal Transverse Mercator (UTM) zone 10 coordinates by:

\footnotetext{
1 The area of this basin has been previously reported as 6.02 and $6.11 \mathrm{~km}^{2}$. These differences are due to different interpretations of the drainage divide.

2 "Middle Tarn" is an unofficial name.

3 A small, debris-covered area of perennial ice lies outside of the Middle Tarn Basin.

4 Salix Creek Basin drainage divides are poorly defined.
} 
UTM easting $=$ local $X(0.99985)+642,000$

UTM northing $=$ local $Y(0.99985)+5,355,000$.

Densities are given as a decimal fraction of the density of water, the density of which is considered to be 1,000 kilograms per cubic meter.

\section{BALANCE YEAR DATA COLLECTION}

\section{$\underline{\text { Recorded Variables }}$}

This report contains recorded data for the water year (WY), October 1, 1996 through September 30,1997. When information concerning these variables is required, but is outside of the WY, the required data are discussed. Digital recorders store either instantaneous values or, for some variables, a value that is averaged over a specific time interval.

Air temperature was measured at the Salix Creek gaging station, the Middle Tarn gaging station, and the Hut (fig. 1). These records are shown graphically (fig. 2). Temperature was measured instantaneously once per hour at each station. Temperature is estimated to be accurate to $\pm 1^{\circ} \mathrm{C}$. Daily maximum (highest of the 24 hourly readings), minimum (lowest of the 24 hourly readings), and average temperatures are given in tables 1-3.

Precipitation was measured at the Salix Creek gaging station (fig. 3). The tipping bucket gage catch was accumulated for 1 hour and recorded digitally. The gage orifice was $200 \mathrm{~mm}$ in diameter and had no wind screen. The precipitation gage was sensitive to $0.024 \mathrm{~mm}$ of precipitation. The gage was in operation during most of the WY, but because no attempt was made to heat the orifice, snow did not readily pass through the tipping bucket.

Salix Creek stage, South Fork Cascade River stage, and Middle Tarn stage were recorded digitally. The sensors are floats with a steel tape driving a potentiometer. Stage records are shown in figure 3. The stage recorders are sensitive to $\pm 3 \mathrm{~mm}$ and are estimated to be accurate to $\pm 3 \mathrm{~mm}$.

An avalanche in late December of 1996 damaged the Middle Tarn instrument enclosure. Repairs were not begun until all the pieces were recovered from the melting snow in early August. The wind speed and direction, precipitation, and ground (snow) temperature sensors were not repaired. Middle Tarn stage and air temperature continue to be recorded on data loggers, but these data are no longer transmitted to central facilities. At the Salix Creek gaging station, low temperatures caused the well to freeze in mid-November, and stage record was lost until early May.

\section{$\underline{\text { Intermittent Measurements }}$}

Snow depth and density; snow, firn, and ice ablation; and river discharge measurements are made during site visits several times during the year. Instruments and facilities are serviced during these visits as well. 
Snow depth was measured by probing at numerous locations on May 9, 1997 (fig. 4, table 4). Snow density was measured in a snow pit extended by coring near P1 (fig. 1) on May 9, 1997 (table 5). The level of snow on four, 33-mm-diameter aluminum stakes (fig. 1) with wood bottom plugs was measured several times during the ablation season (table 6, fig. 5).

Aerial photography recorded the condition of the glacier on September 23, 1997 (fig 6). Measurements of the size and shape of the glacier, and location of transient snow lines are made from the stereo aerial photography. An altitude grid of the glacier was formed by photogrammetric measurement of altitude at a regular $100-\mathrm{m}$ spacing over the area of the glacier, the altitudes of which are estimated to be accurate to $\pm 2 \mathrm{~m}$, and shown in figure 7 and table 7 . The terminus of the glacier (fig. 8) was digitized from the photographs by measuring the locations of numerous points along the edge of the glacier. The location of the points is estimated to be accurate to $\pm 1 \mathrm{~m}$. The area of the glacier near the end of the 1996 balance year was $2.015 \mathrm{~km}^{2}$ (Krimmel, 1997). Assuming that the area of the glacier south of $Y=3,200 \mathrm{~m}$ is unchanged since 1996, the area of the glacier near the end of the 1997 balance year was $1.995 \mathrm{~km}^{2}$. The terminal ice retreated from its 1996 position almost everywhere along the terminus, and the retreat from 1996-97 was subjectively averaged to be $18 \mathrm{~m}$ (fig. 8). However, the end-of-year snow-and-icecovered area within the South Cascade Glacier basin was greater in 1997 than it was in 1996, because more snow remained at the end of the 1997 balance year. Almost no 1996 firn (snow that fell in 1996, but remains in 1997) can be seen on the September 23, 1997 photographs.

The transient snowline is clearly visible on the September 23, 1997 vertical photographs, and the position of that transient snowline is shown on figure 1 . The highest position on the glacier obtained by the transient snowline is the equilibrium line (fig. 1), the position of which was estimated by considering ablation measurements at the stakes. The average altitude of points spaced at regular intervals along the equilibrium line is the equilibrium line altitude, $1857 \mathrm{~m}$. The ratio of the accumulation area to the total glacier area was 0.70 in $1997^{5}$.

\section{DATA REDUCTION}

\section{Precipitation}

A precipitation gage at the Salix Creek gaging station was in operation from October 1 to late April, from early June to early August, and from mid August to the end of the 1997 WY. Incremental precipitation gage catch was accumulated for each day, and the daily total precipitation is shown graphically in figure 9 and table 8 .

The Salix Creek precipitation measurement site is not considered to be representative of either basin because of local variations in precipitation, the difficulty of measuring precipitation when the weather is windy, and the difficulty of measuring precipitation that falls as snow. The importance of the record is to compare it with records from other years, to indicate the time of precipitation events, and to indicate general precipitation conditions.

5 For balance year 1996, the accumulation area ratio was incorrectly reported as 0.40 (Krimmel, 1997). The 1996 accumulation area ratio was 0.61 . 


\section{Salix Creek Runoff}

Salix Creek stage measurements (fig. 3) are converted to instantaneous discharge values, which are averaged for each day and converted to a basin-averaged daily runoff (fig. 9, table 9). The Salix Creek stage recorder failed in mid-November, and was not re-started until early May, resulting in lost record. The flow of Salix Creek at the gaging station is controlled by a weir supported by bedrock. No visible changes of the control occurred during the year; thus, the rating curve used to convert stage to discharge was the same as has been used since the measurements began in 1960 :

$$
\mathrm{q}=\mathrm{S}^{2.57 * 2.71}
$$

where $\mathrm{q}$ is discharge in cubic feet per second and $\mathrm{S}$ is stage in feet. The equations for the rating curve is in English units for the convenience of the author and reader, because the original stage data are in feet and the machine-readable files are in feet. Except in these two instances, stage has been converted to meters.

\section{South Fork Cascade River Runoff}

South Fork Cascade River stage measurements (fig. 3) are similarly converted to instantaneous discharge values, which are averaged for each day and converted to a basinaveraged daily runoff (fig. 9, table 10). The controlling weir is built on glacial outwash and moraine material, and is known to be unstable. Visual inspection of the weir and surrounding foundation and diversion walls indicated that changes were minor from 1996 to 1997. Three discharge measurements made in 1997 indicated that the 1996 rating curve remained valid for 1997. The rating curve used to convert stage to discharge was that used in 1996.

For stage below 0.87 foot:

$$
q=0.0036+5.62 * S-5.57 * S^{2}+14.74 * S^{3}
$$

For stage above 0.86 foot:

$$
q=17.45-43.14 * S+40.94 * S^{2}-0.90 * S^{3}
$$

Because of suspected changes in the weir during the year, the errors in the South Fork Cascade River discharge calculations may be \pm 20 percent of the determined values.

\section{Middle Tarn Runoff}

Stage measurements (fig. 3) were converted to discharge, and subsequently to runoff (fig. 9 , table 11), using a rating curve determined from 14 discharge measurements made between September 8, 1992 and September 16, 1994. The outlet from Middle Tarn is a bedrock channel that does not change; therefore, the rating curve is expected to remain stable at Middle Tarn. For stages above 0.35 foot,

$$
q=2.064-3.673 * S+24.770 * S^{2},
$$

and at a stage of 0.35 foot and below,

$$
\mathrm{q}=\mathrm{S}^{1.809 * 25.123 .}
$$


The Middle Tarn stage recorder failed in early December and was not restarted until early August, resulting in lost record.

\section{MASS BALANCE}

\section{Winter Balance}

Balance was measured on May 9, 1997 near the time of maximum accumulation. Snow depth was measured at 42 places at altitudes ranging from 1,619 to $2,077 \mathrm{~m}$ using a $10-\mathrm{mm}$ diameter probe rod (fig. 4, table 4). The 1996 summer surface could commonly be detected, although above $1,900 \mathrm{~m}$ altitude, ice layers made probing less certain. Probing locations were determined with a non-differential GPS that was encrypted to allow $10 \mathrm{~m}$ accuracy of horizontal and vertical locations (fig. 4, table 4). Snow density was measured in a pit at $1,836 \mathrm{~m}$ altitude (to $1.2 \mathrm{~m}$ depth), followed by coring from the floor of the pit to the 1996 summer surface to a total depth of $7.06 \mathrm{~m}$.

Snow depth measurements were plotted as a function of altitude, and a hand-drawn smoothed curve fit to the points (fig. 10). Points were extracted from the smoothed curve (table 12) and a piecewise linear interpolation was used to determine the snow depth at the altitude of every point of the 1997 altitude grid. The average snow density at $1,836 \mathrm{~m}$ altitude was 0.49 $\mathrm{kg} / \mathrm{m}^{3}$ (table 5 ). Density was measured at only one place, but since typically the snowpack becomes less dense as the altitude increases, a density gradient of $-0.02 \mathrm{~kg} / \mathrm{m}^{3}$ per $100 \mathrm{~m}$ altitude was assumed. The balance on May 9 was calculated by summing the snow water content at every point in the altitude grid using the grid-index method described by Krimmel (1996b). The measured winter balance, $\bar{b}_{\mathrm{m}}(\mathrm{s})$, was calculated to be $3.71 \mathrm{~m}$.

The maximum winter balance, $\bar{b}_{x}(\mathrm{~s})$, probably occurred within a few days before May 9 . The first major rise in runoff recorded at the South Fork Cascade River gaging station began on May 9, and the air temperature at the Hut (217 m higher) was near freezing until early May, at which time daily average temperatures climbed above freezing. No adjustment was necessary between $\bar{b}_{\mathrm{m}}(\mathrm{s})$ and $\bar{b}_{\mathrm{x}}(\mathrm{s})$.

\section{Net Balance}

Balance was measured near the end of the ablation season on September 20, 1997 by coring through the remaining snow cover or, in areas where no snow remained, by measuring previously set stakes. A hand-driven auger extracted a vertical sample of the snow specifically to find the underlying 1996 summer surface. The 1996 summer surface was easily identified as a dirt horizon in the extracted cores, and the depth to that surface was measured. Four cores were taken between 1,860 and 2,030 m altitude (fig. 1, table 6). The loss of firn or ice was measured at four stakes on the lower glacier (fig. 1, table 6) in areas where all the snow melted. Ablation continued after the last measurement in the balance year was made on September 20. The final measurement at the four stakes was made to the summer surface (buried under snow that fell after September 20) on November 4, 1997. These measurements determined the amount of melt after September 20. This late-season melt rate was extrapolated to measurements at the core sites, 
thus providing an altitude distribution from 1,638 to $2,030 \mathrm{~m}$ of 1997 snow accumulation or ice ablation. Snow density was not measured, but from late season snow density measurements in previous years, it was assumed that $0.6 \mathrm{~kg} / \mathrm{m}^{3}$ was a reasonable value to use at all core locations where snow remained at the end of the ablation season.

The net balance at each of the four core and four stake locations was plotted (fig. 11) and a hand-drawn smooth curve was fitted to the points. Points were extracted from the smooth curve (table 13), and a piecewise linear interpolation was used to determine the balance at every point of the 1997 altitude grid, from which the net balance could be determined using the grid-index method.

Net balance was calculated to be $0.63 \mathrm{~m}$.

\section{Balance Year to Water Year Adjustments}

The final balance increment, $\bar{b}_{1}$, for the 1996 balance year was estimated at $-0.15 \mathrm{~m}$ water equivalent (WE) (Krimmel, 1997). This value becomes the initial balance increment, $\bar{b}_{0}$, for the 1997 balance year.

A storm in late September 1997 probably began as rain over the entire glacier, but by October 4, when the air temperature at $1,848 \mathrm{~m}$ altitude went below freezing, the precipitation was snow over much of the glacier area. The 1998 balance year began on about October 4, 1997. Mild, dry conditions prevailed from October 12-21, but it is unlikely that enough of the previous storm's snow melted to reduce the total mass of the glacier to less than that just before October 4 . By the time of a field visit on November 4, 1997, the lower glacier was covered with 0.20 to $0.30 \mathrm{~m}$ of snow, and at $1,836 \mathrm{~m}$ snow was more than $1 \mathrm{~m}$ thick.

The change in mass between the end of the water year and the end of the balance year is the final balance increment, $\bar{b}_{1}$, and because the temperature was cool during the late September storm, very little ablation occurred between October 1 and October 4,1997 . Thus $\bar{b}_{1}$ is assumed to be $0.0 \mathrm{~m}$.

The annual balance, $\bar{b}_{\mathrm{a}}$, is defined by Mayo and others (1972) as the change in snow, firn, and ice storage between the beginning and end of a fixed period, which here is the water year. The measured values of $\bar{b}_{0}, \bar{b}_{1}$, and $\bar{b}_{\mathrm{n}}$ at South Cascade Glacier for the 1997 balance year can be used to derive the annual balance, $\bar{b}_{\mathrm{a}}$, where $\bar{b}_{\mathrm{a}}=\bar{b}_{\mathrm{n}}+\bar{b}_{0}-\bar{b}_{1}=0.48 \mathrm{~m}$.

\section{Balance Measurement Errors}

Errors in glacier balance measurements are difficult to quantify. In prior years of balance measurements at South Cascade Glacier, error values ranging around $0.10 \mathrm{~m}$ were placed on the balance values (Meier and others, 1971). In 1965 and 1966, more information was used to derive the balances than in 1992-96. The availability of less information in 1996 would suggest that greater errors should be assigned to the 1996 balance. The relative paucity of data for 1997 is offset somewhat, however, by the experience gained since the mid-1960's, when 20 to 30 ablation 
stakes were used and it was found that spatial variations in balance were similar from year to year (Meier and Tangborn, 1965). Estimated errors are $\bar{b}_{\mathrm{m}}(\mathrm{s}), \bar{b}_{\mathrm{x}}(\mathrm{s})$, and $\bar{b}_{\mathrm{n}}, \pm 0.20 \mathrm{~m} ; \bar{b}_{0}$ and $\bar{b}_{1}$, $\pm 0.05 \mathrm{~m}$; and the calculated error for $\bar{b}_{\mathrm{a}}$ is $\pm 0.21 \mathrm{~m}$. Although other factors that affect the balance, such as internal accumulation of ice, superimposed ice, internal melt, and basal melt, are possible, they are not considered in this report. These unknowns are thought to be small and do not change the error estimations.

\section{LONG-TERM BALANCE RECORD}

In 1997, the net balance of South Cascade Glacier was the most positive since 1976. Even so, the net balance was not exceptional because the net balances in 1959, 1964, 1972, 1974, and 1976 (table 14) were greater than that in 1997 . The 1997 net balance was $1.57 \mathrm{~m}$ greater than the $1977-96$ average $(-0.94 \mathrm{~m})$. Winter balance was the most positive since 1972 , and was the second most positive on record.

Despite the strong positive net balance and the second successive positive net balance, the glacier terminus has continued to retreat.

\section{REFERENCES CITED}

Fountain, A.G., Krimmel, R.M., and Trabant, D.C., 1997, A strategy for monitoring glaciers:

U.S. Geological Survey Circular 1132, 20 p.

Krimmel, R.M., 1989, Mass balance and volume of South Cascade Glacier, Washington, 1958-1985, in Oerlemans, J., ed., Glacier fluctuations and climatic change: Dordrecht, Netherlands, Kluwer Academic Publishers, p. 193-206.

----- 1993, Mass balance, meteorological, and runoff measurements at South Cascade Glacier, Washington, 1992 balance year: U.S. Geological Survey Open-File Report 93-640, 38 p.

----- 1994, Runoff, precipitation, mass balance, and ice velocity measurements at South Cascade Glacier, Washington, 1993 balance year: U.S. Geological Survey Water-Resources Investigations Report 94-4139, 35 p.

----- 1995, Water, ice, and meteorological measurements at South Cascade Glacier, Washington, 1994 balance year: U.S. Geological Survey Water-Resources Investigations Report 95-4162, $41 \mathrm{p}$.

1996a, Water, ice, and meteorological measurements at South Cascade Glacier, Washington, 1995 balance year: U.S. Geological Survey Water-Resources Investigations Report 96-4174, 37 p.

-.--- 1996b, Glacier mass balance using the grid-index method, in Colbeck, S.C., ed., Glaciers, ice sheets and volcanoes: A tribute to Mark F. Meier: U.S. Army Corps of Engineers Cold Regions Research and Engineering Laboratory Special Report 96-27, p. 62-68.

1997, Water, ice, and meteorological measurements at South Cascade Glacier, Washington, 1996 balance year: U.S. Geological Survey Water-Resources Investigations Report 97-4143, $34 \mathrm{p}$. 
Mayo, L.R., Meier, M.F., and Tangborn, W.V., 1972, A system to combine stratigraphic and annual mass-balance systems--A contribution to the International Hydrological Decade: Journal of Glaciology, v. 11, no. 61, p. 3-14.

Meier, M.F., and Tangborn, W.V., 1965, Net budget and flow of South Cascade Glacier, Washington: Journal of Glaciology, v. 5, no. 41, p. 547-566.

Meier, M.F., Tangborn, W.V., Mayo, L.R., and Post, Austin, 1971, Combined ice and water balances of Gulkana and Wolverine Glaciers, Alaska, and South Cascade Glacier, Washington, 1965 and 1966 water years: U.S. Geological Survey Professional Paper 715-A, $23 \mathrm{p}$.

Østrem, G., and Brugman, M., 1991, Glacier mass-balance measurements--A manual for field and office work: Environment Canada, National Hydrology Research Institute Science Report No. 4, $224 \mathrm{p}$.

Sullivan, M.E., 1994, South Cascade Glacier, Washington--Hydrologic and meteorological data, 1957-67: U.S. Geological Survey Open-File Report 94-77, 105 p.

Tangborn, W.V., Mayo, L.R., Scully, D.R., and Krimmel, R.M., 1977, Combined ice and water balances of Maclure Glacier, California, South Cascade Glacier, Washington, and Wolverine and Gulkana Glaciers, Alaska, 1967 water year: U.S. Geological Survey Professional Paper 715-B, $20 \mathrm{p}$. 


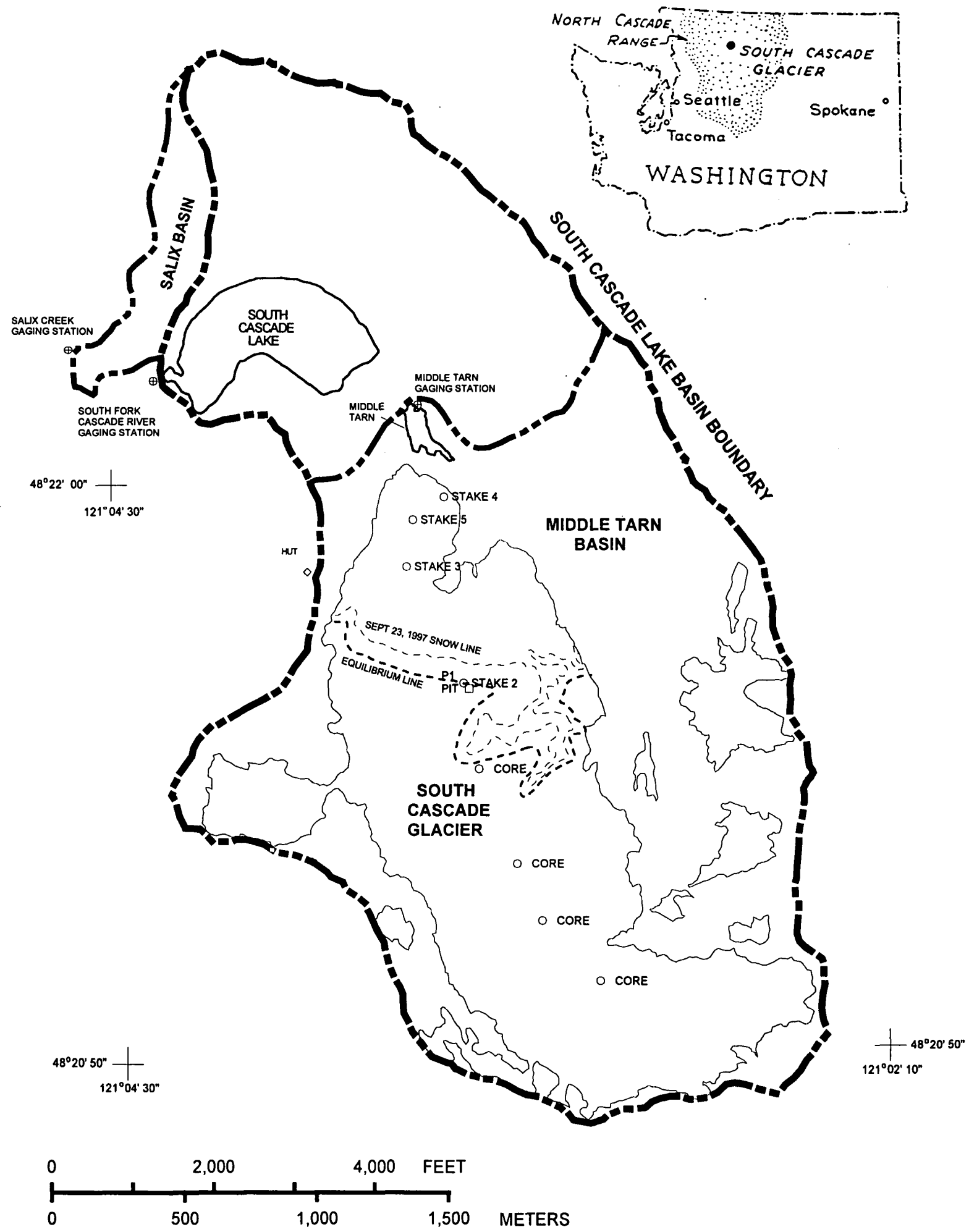

FIGURE 1. South Cascade Glacier and vicinity. 


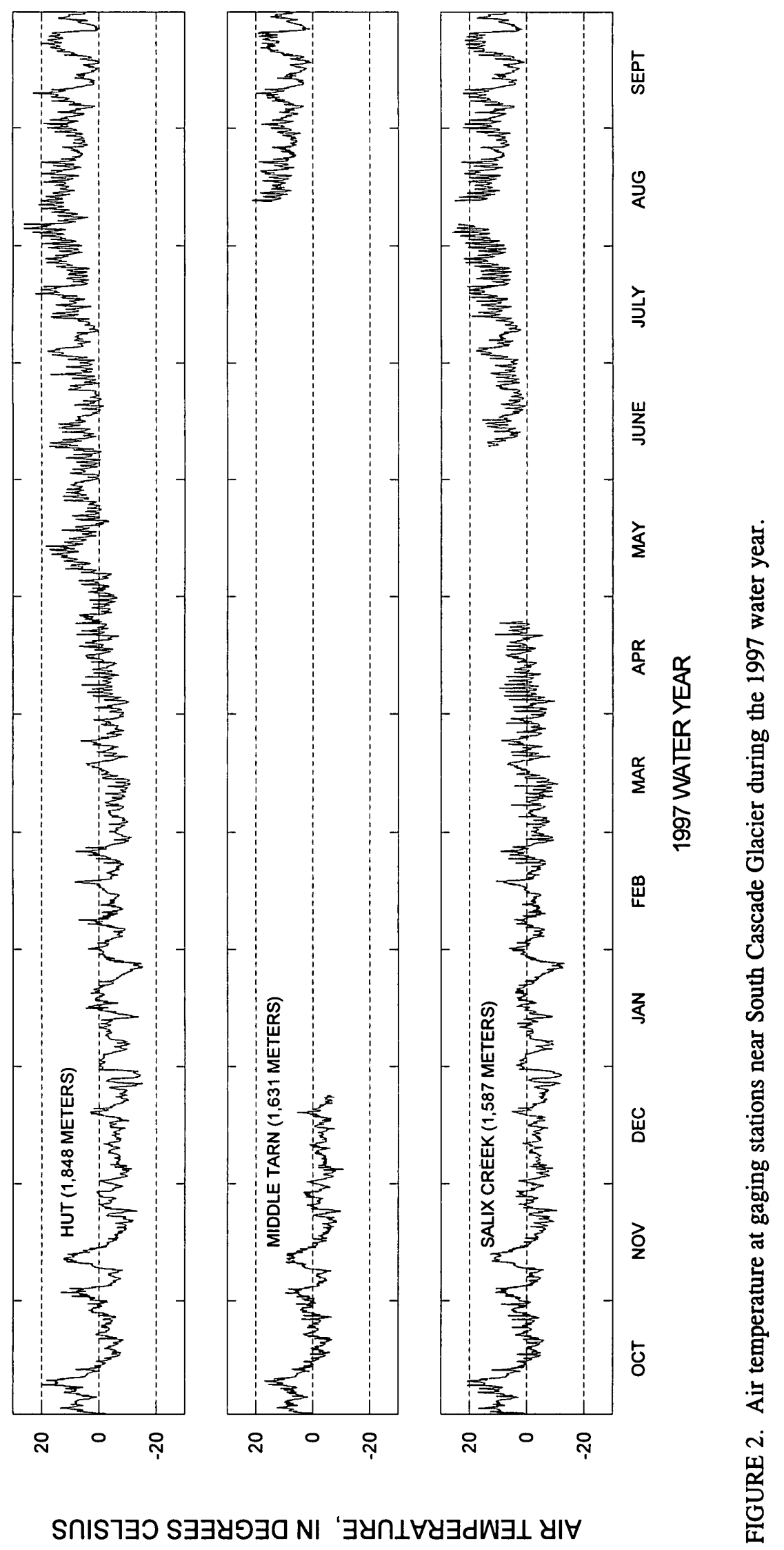




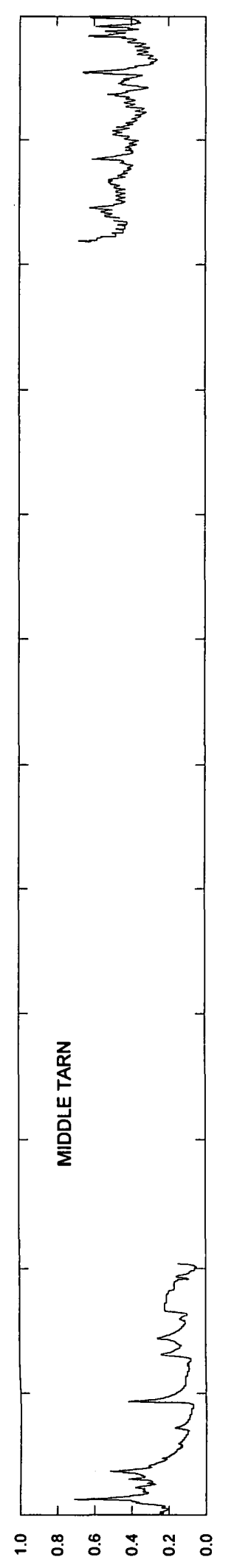

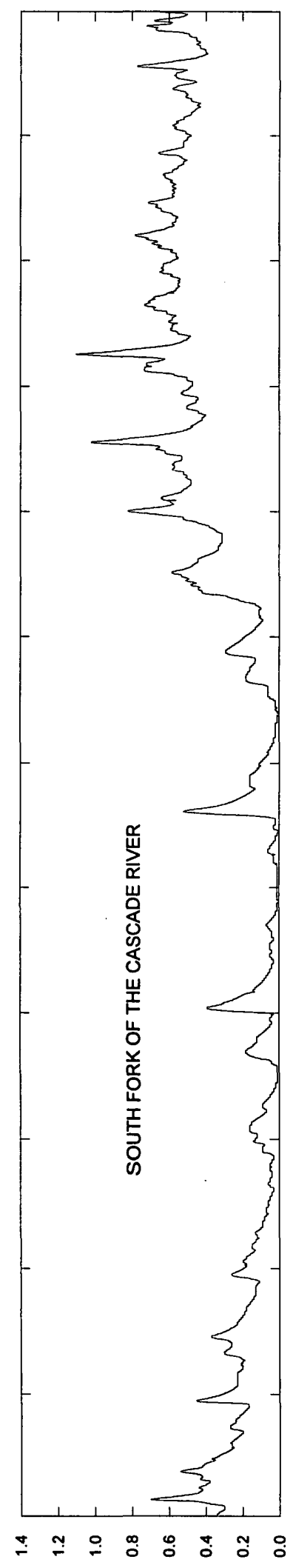

SУヨLヨWNI' $\exists \supset \forall \perp S$
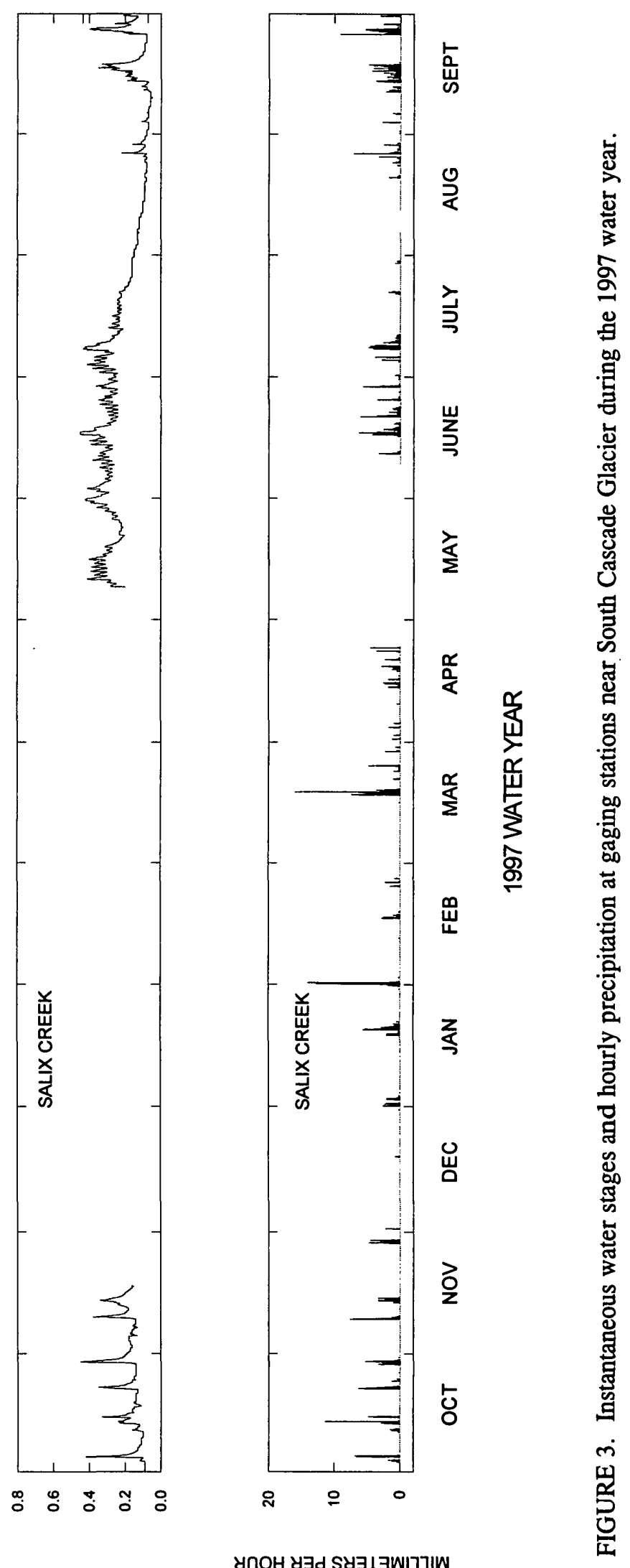

NI 'NOIL $\forall \perp l d I O \exists y d$ 


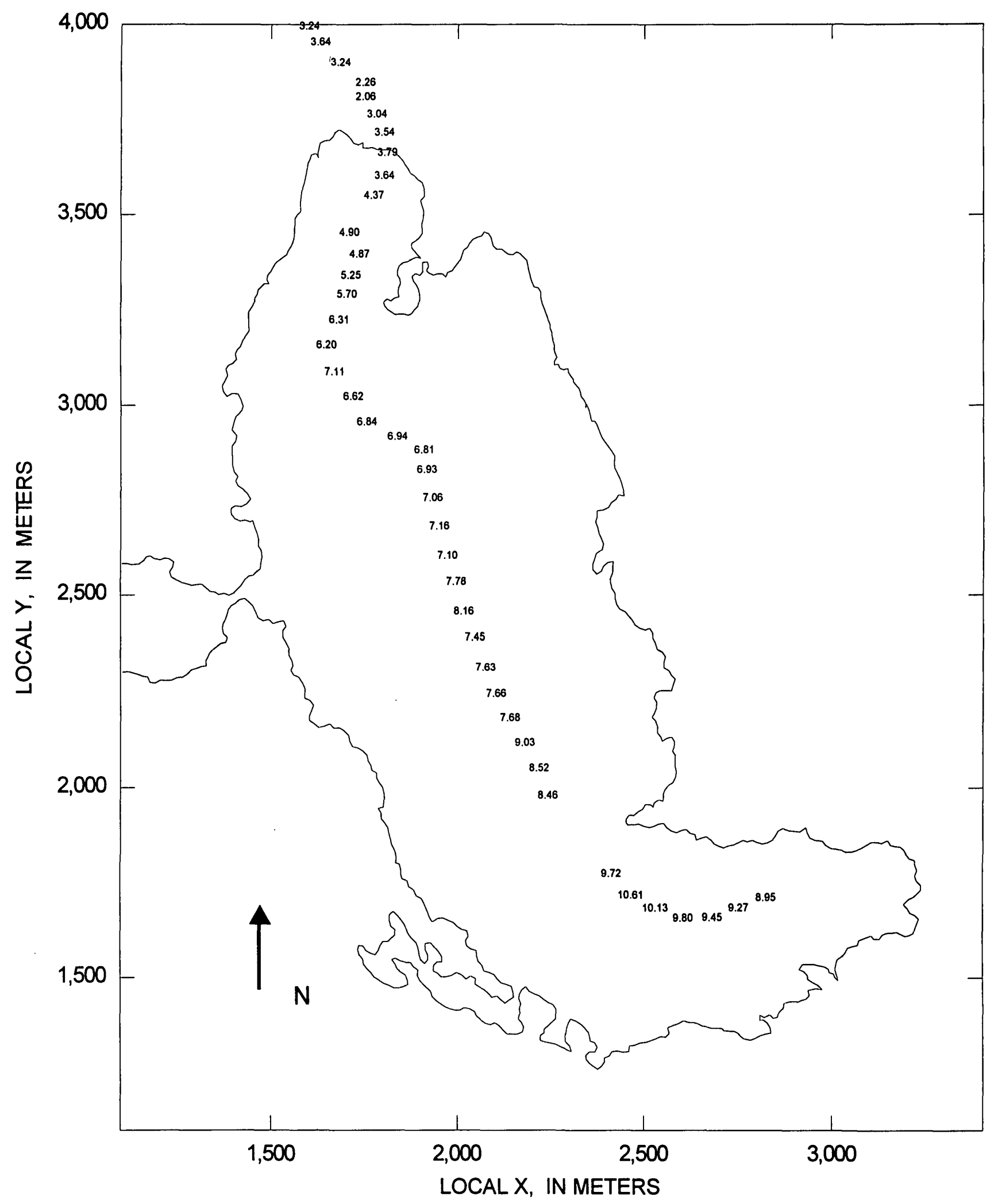

FIGURE 4. Snow depths, in meters, on South Cascade Glacier on May 9, 1997. 


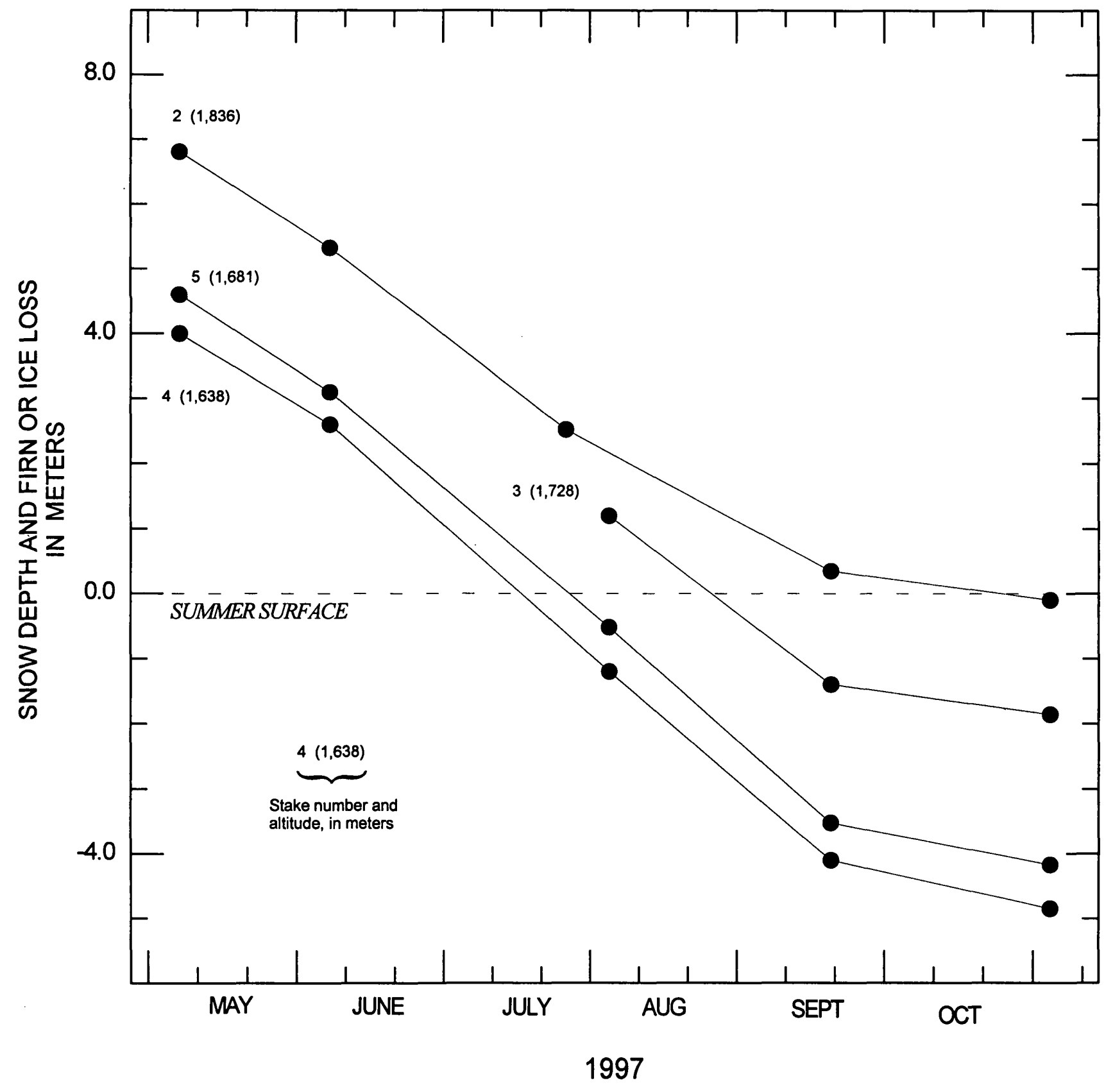

FIGURE 5. Snow depth and firn or ice loss at South Cascade Glacier at each 1997 stake. Depths are accurate to 0.1 meter. Stake locations shown in figure 1 . 


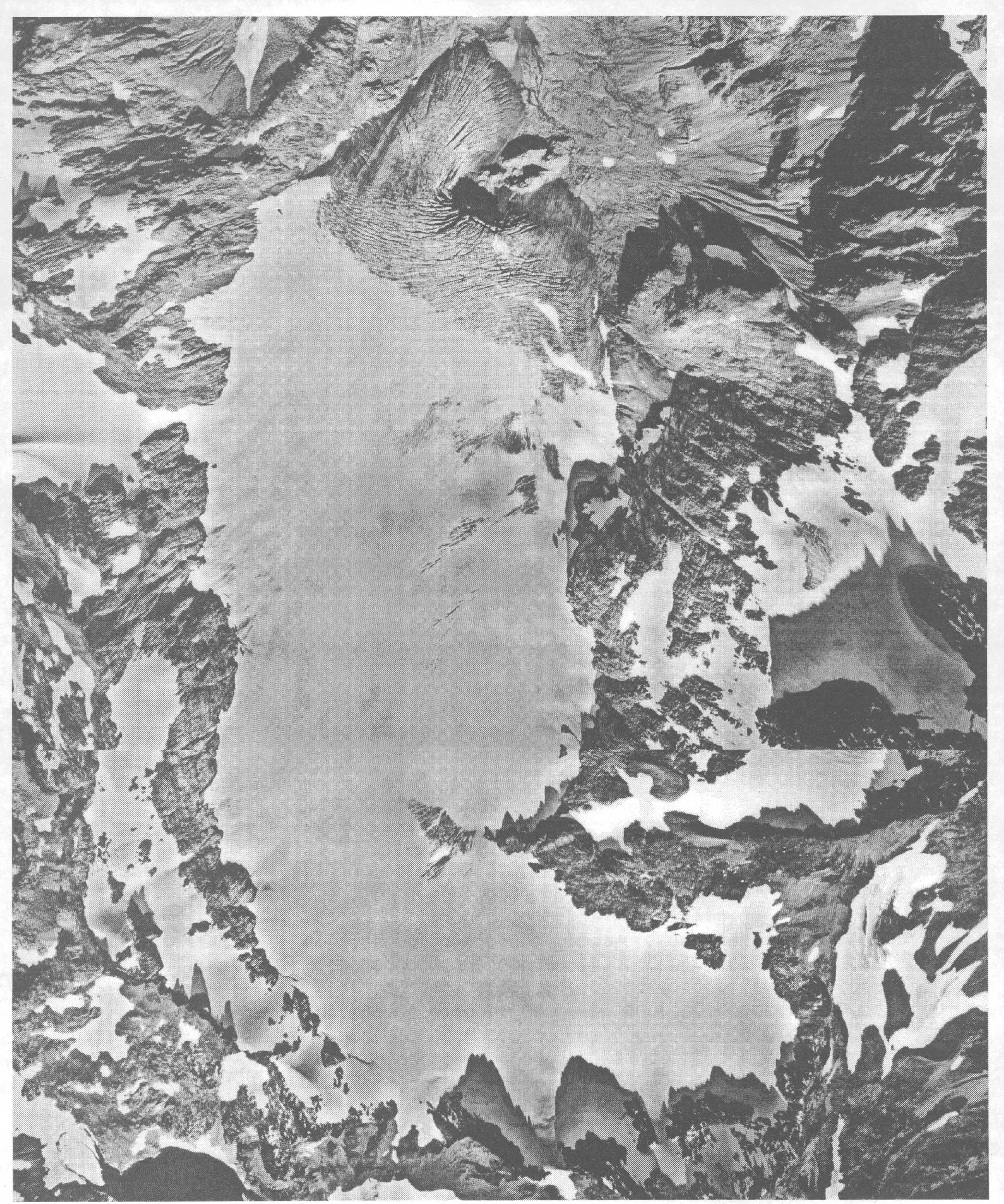

Figure 6. Vertical photograph of South Cascade Glacier, September 23, 1997. The maximum width of the glacier is about $1 \mathrm{~km}$, north is approximately up. Mosaic of photographs 97V2-153 and 154. 


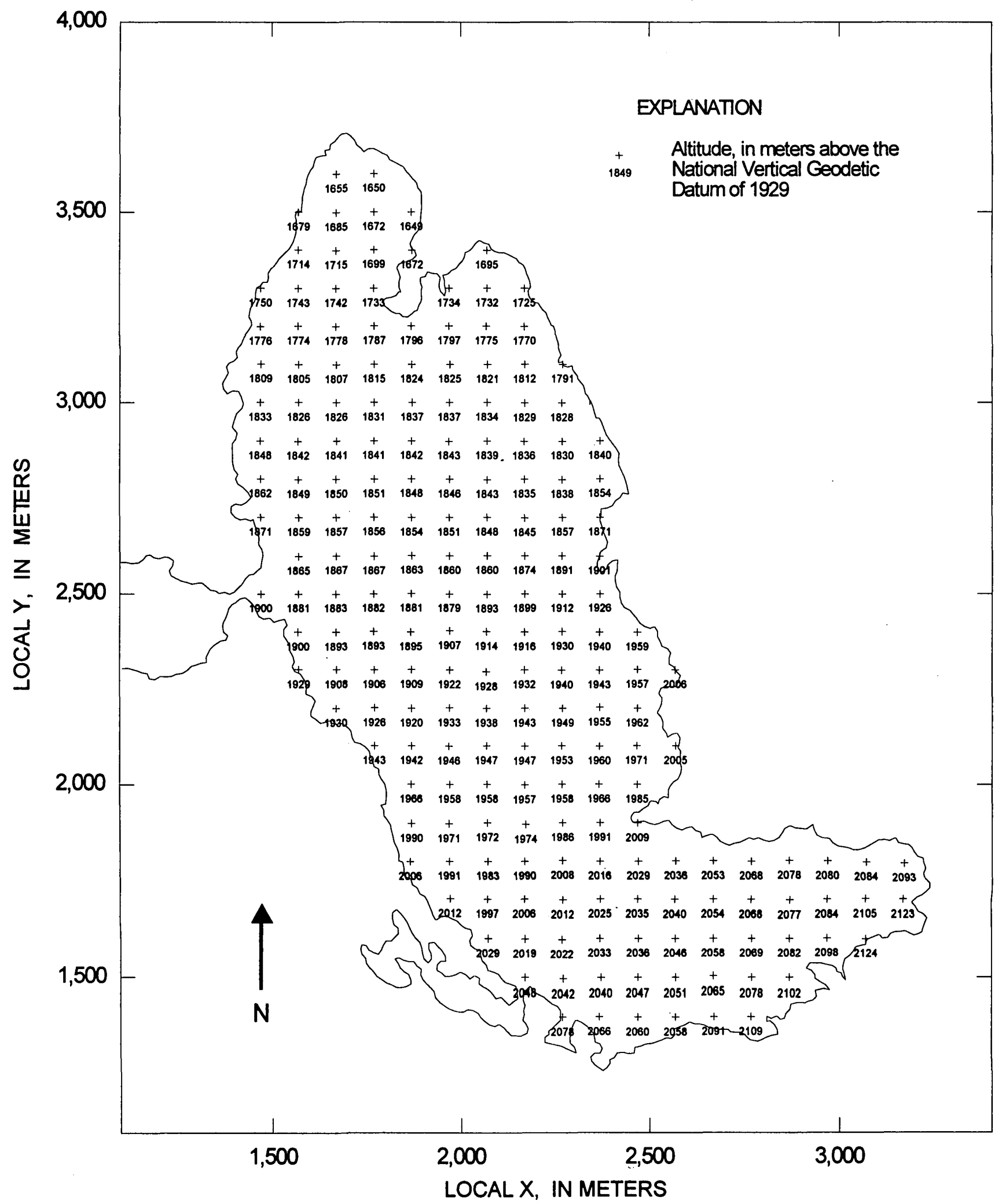

FIGURE 7. Altitude grid for South Cascade Glacier, measured from stereo vertical photographs taken on September 23, 1997. 


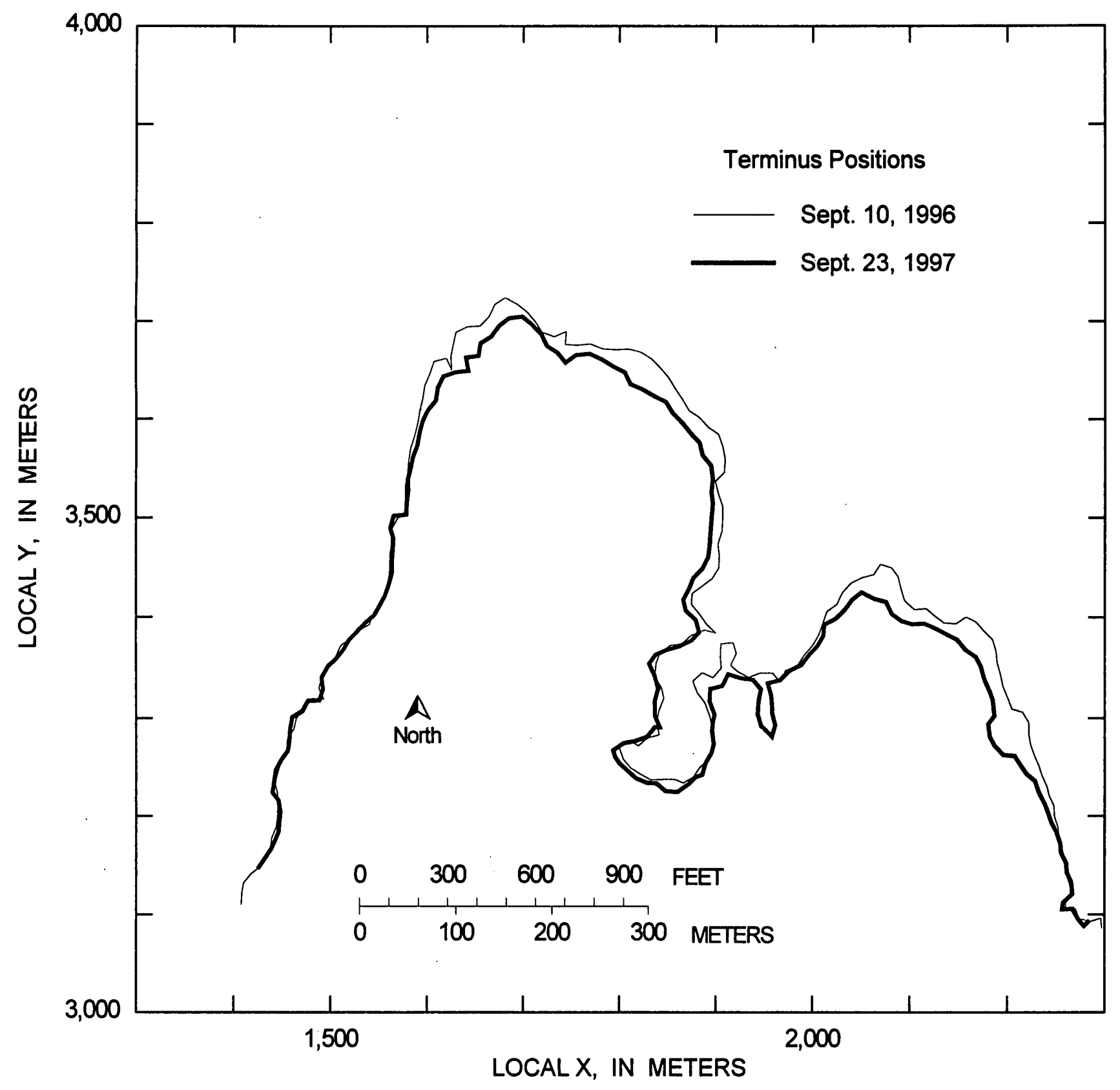

FIGURE 8. South Cascade Glacier terminus positions for September 10, 1996, and September 23, 1997. 

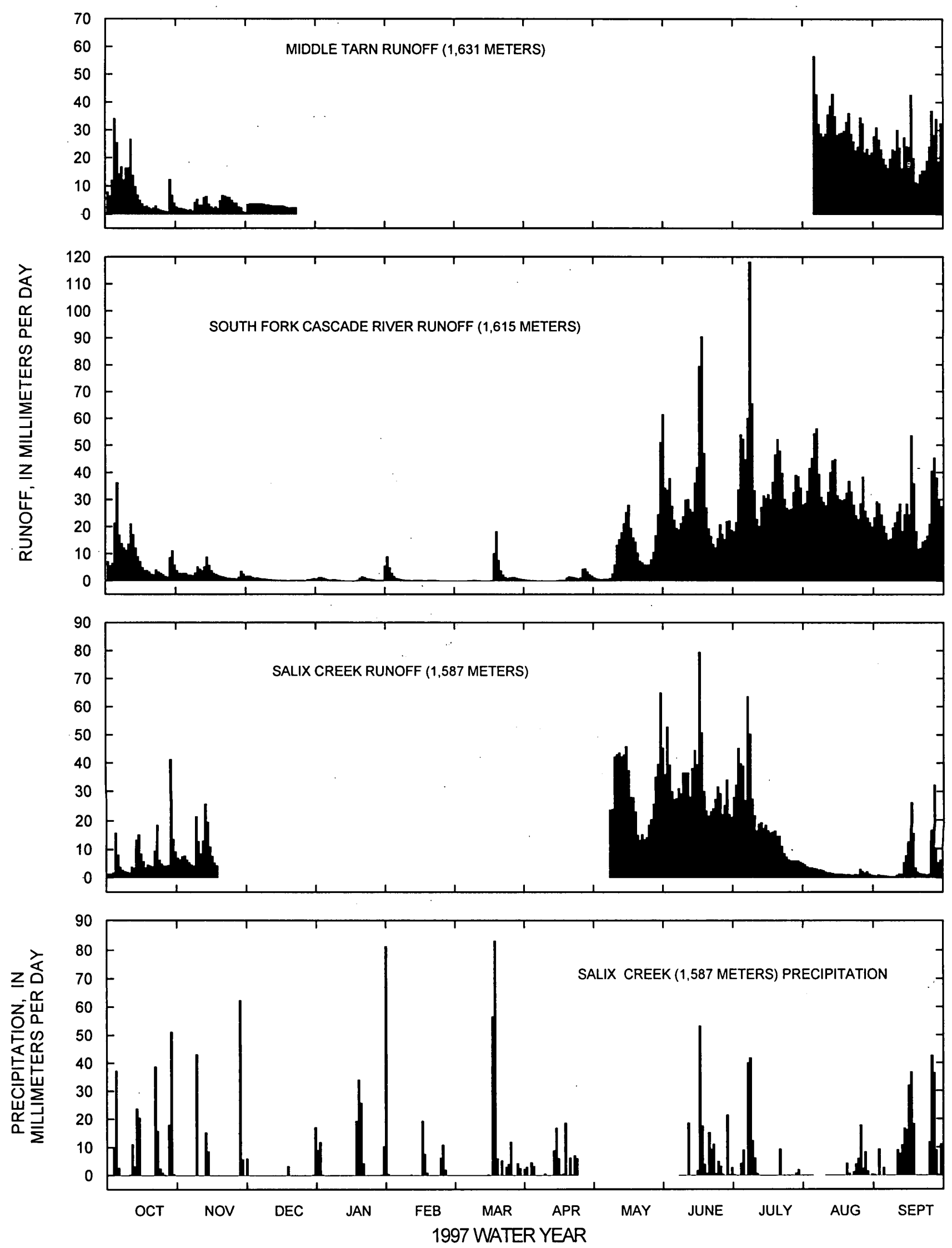

FIGURE 9. Daily runoff and precipitation at gaging stations near South Cascade Glacier during the 1997 water year. Data are missing when no "zero" line is shown. 


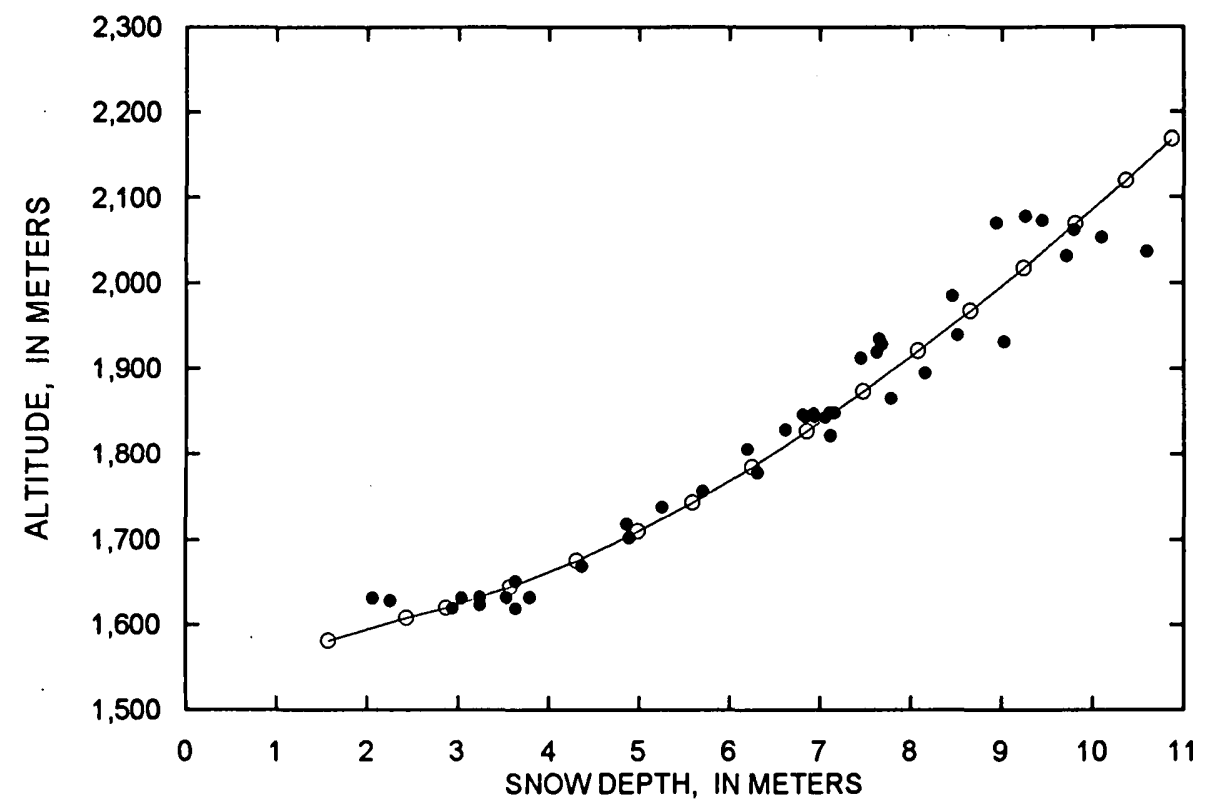

FIGURE 10. Snow depth as a function of altitude at South Cascade Glacier, May 9, 1997. Solid circles are measured, open circles are points along a hand-drawn curve used for interpolation.

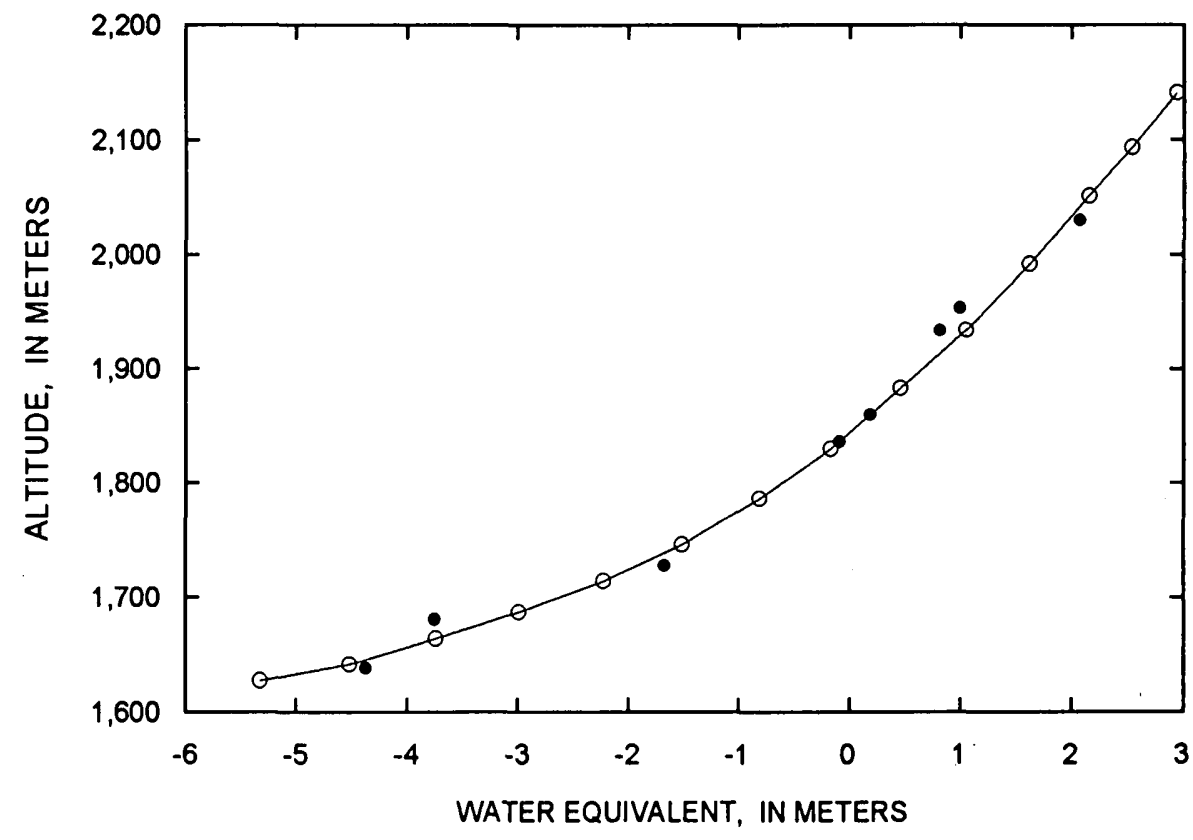

FIGURE 11. Net balance as a function of altitude at South Cascade Glacier, 1997. Solid circles are measured, open circles are along a hand-drawn curve used for interpolation. 


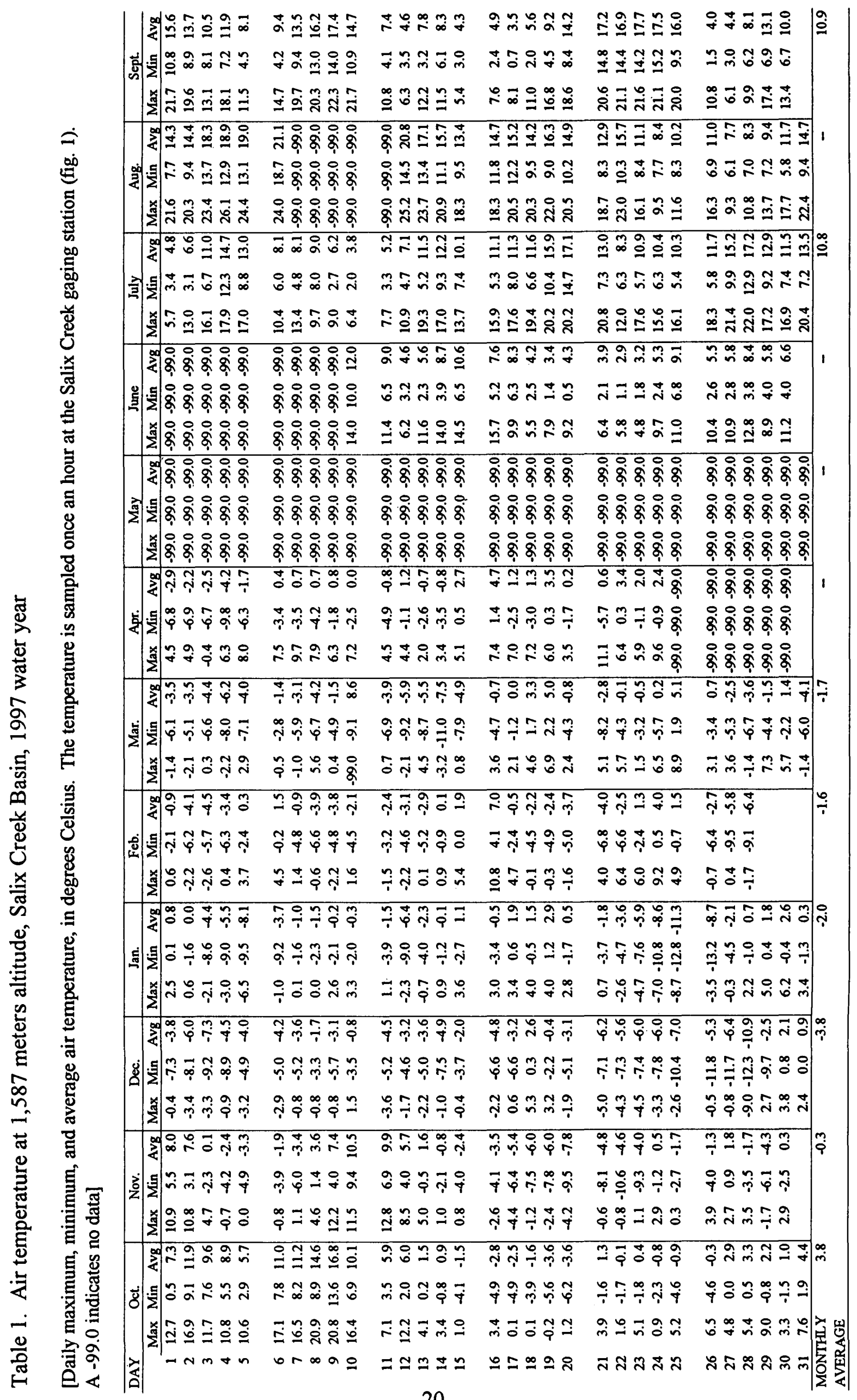




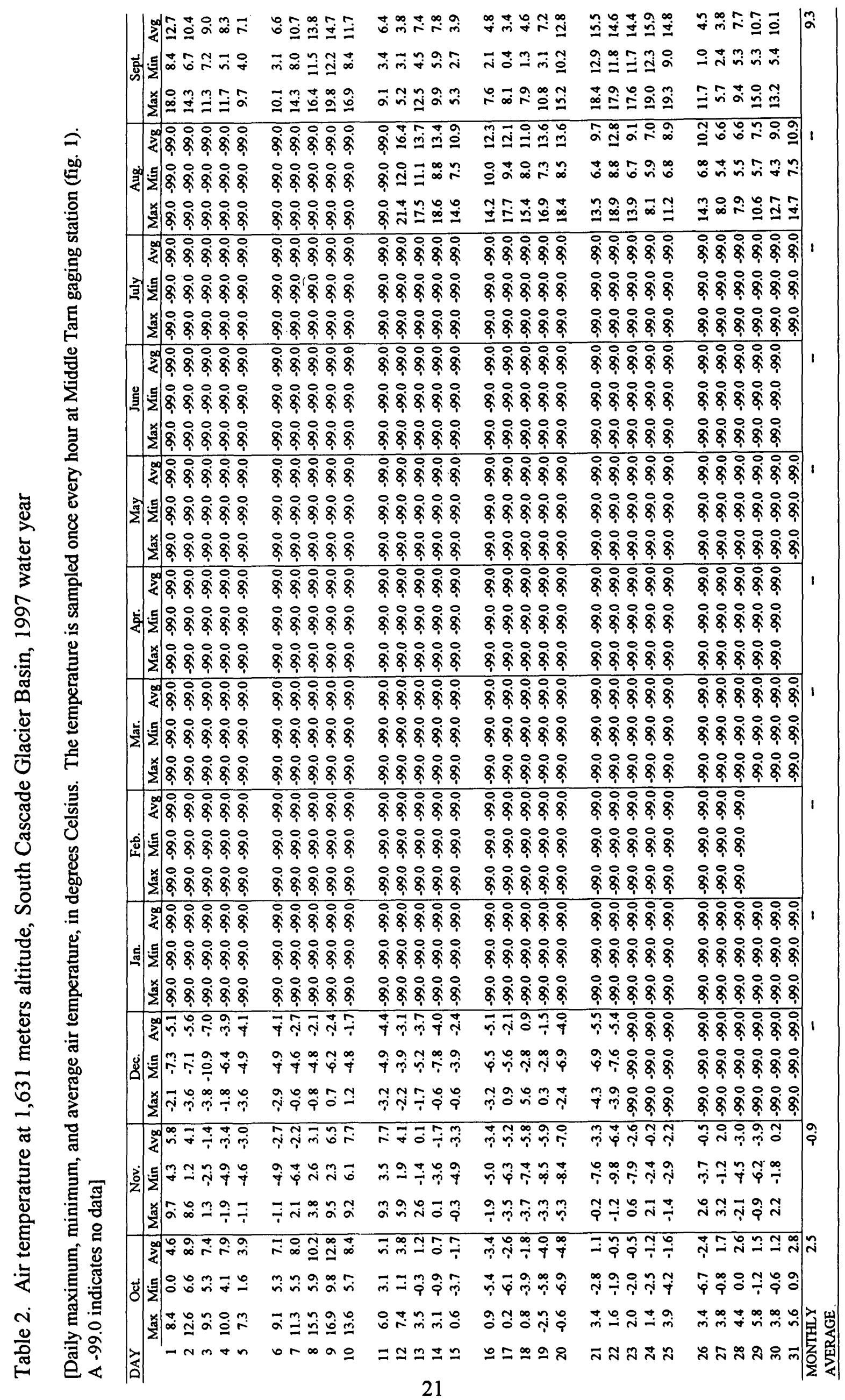




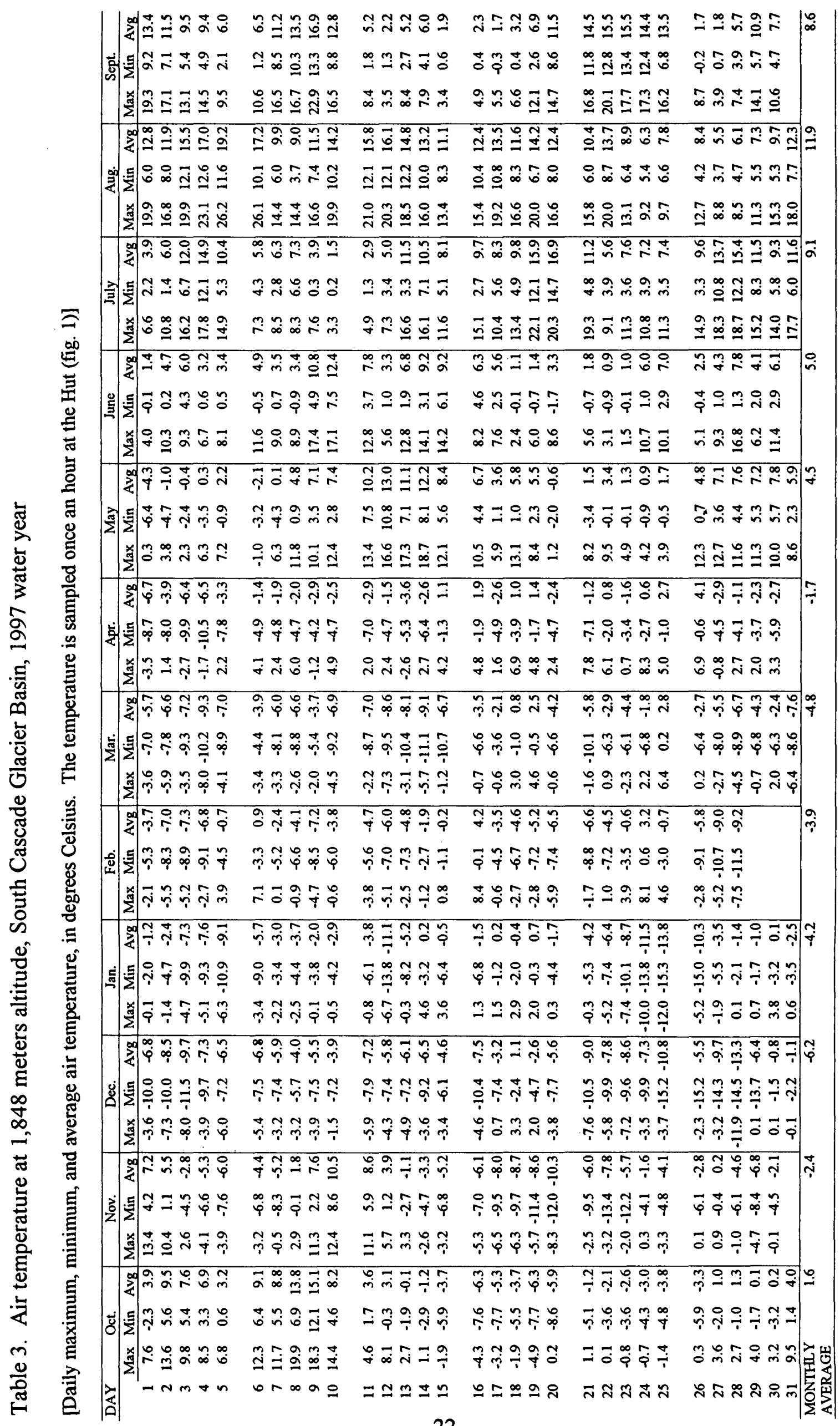


Table 4. Snow depths at South Cascade Glacier, May 9, 1997

[Depths, in meters (m) measured with a probe rod; $X$ and $Y$ are local coordinates, \pm 10 meters. Surface altitude (Z), in meters above National Geodetic Vertical Datum of 1929]

\begin{tabular}{|c|c|c|c|c|c|c|c|c|c|c|c|c|c|c|c|}
\hline$x$ & $\mathrm{Y}$ & Z & $\begin{array}{l}\text { Snow } \\
\text { depth } \\
\text { (m) }\end{array}$ & $\mathrm{X}$ & $Y$ & Z & $\begin{array}{c}\text { Snow } \\
\text { depth } \\
\text { (m) }\end{array}$ & $x$ & $Y$ & Z & $\begin{array}{l}\text { Snow } \\
\text { depth } \\
\text { (m) }\end{array}$ & $X$ & $Y$ & Z & $\begin{array}{l}\text { Snow } \\
\text { depth } \\
\text { (m) }\end{array}$ \\
\hline 2826 & 1711 & 2070 & 8.95 & 2105 & 2250 & 1934 & 7.66 & 1757 & 2957 & 1844 & 6.84 & 1802 & 3604 & 1650 & 3.64 \\
\hline 2753 & 1684 & 2077 & 9.27 & 2076 & 2317 & 1919 & 7.63 & 1720 & 3024 & 1828 & 6.62 & 1811 & 3665 & 1632 & 3.79 \\
\hline 2683 & 1659 & 2072 & 9.45 & 2047 & 2391 & 1913 & 7.45 & 1670 & 3088 & 1822 & 7.11 & 1803 & 3718 & 1632 & 3.54 \\
\hline 2605 & 1657 & 2062 & 9.80 & 2017 & 2458 & 1895 & 8.16 & 1649 & 3158 & 1806 & 6.20 & 1782 & 3766 & 1631 & 3.04 \\
\hline 2531 & 1683 & 2053 & 10.13 & 1997 & 2536 & 1865 & 7.78 & 1682 & 3223 & 1778 & 6.31 & 1752 & 3812 & 1631 & 2.06 \\
\hline 2466 & 1717 & 2036 & 10.61 & 1973 & 2605 & 1848 & 7.10 & 1702 & 3290 & 1756 & 5.70 & 1752 & 3849 & 1628 & 2.26 \\
\hline 2414 & 1774 & 2031 & 9.72 & 1951 & 2682 & 1848 & 7.16 & 1713 & 3340 & 1738 & 5.25 & 1685 & 3902 & 1632 & 3.24 \\
\hline 2243 & 1980 & 1985 & 8.46 & 1933 & 2757 & 1843 & 7.06 & 1735 & 3396 & 1718 & 4.87 & 1631 & 3955 & 1619 & 3.64 \\
\hline 2220 & 2053 & 1939 & 8.52 & 1917 & 2832 & 1847 & 6.93 & 1708 & 3453 & 1702 & 4.90 & 1601 & 3997 & 1623 & 3.24 \\
\hline 2182 & 2120 & 1931 & 9.03 & 1910 & 2884 & 1846 & 6.81 & 1775 & 3551 & 1669 & 4.37 & & & & \\
\hline 2142 & 2186 & 1928 & 7.68 & 1839 & 2919 & 1844 & 6.94 & & & & & & & & \\
\hline
\end{tabular}

Table 5. Snow density at South Cascade

Glacier, May 9, 1997

[Measured in a snow pit, extended by coring, through the entire thickness of the snow, at local $X=1910, Y=2884, Z=1836$ meters. Diameter of snow tube used in pit $=0.0723$ meter, of coring auger $=0.0763$ meter]

\begin{tabular}{cccc}
\hline $\begin{array}{c}\text { Sample } \\
\text { bottom } \\
\text { depth } \\
\text { (meters) }\end{array}$ & $\begin{array}{c}\text { Sample } \\
\text { length } \\
\text { (meters) }\end{array}$ & $\begin{array}{c}\text { Mass } \\
\text { (kilograms) }\end{array}$ & Density \\
\hline 0.48 & 0.48 & 0.640 & 0.33 \\
.92 & .44 & .790 & .44 \\
1.20 & .28 & .530 & .46 \\
Begin using coring auger & & \\
1.71 & .51 & 1.140 & .49 \\
1.96 & .25 & .535 & .47 \\
2.68 & .72 & 1.520 & .46 \\
3.16 & .48 & 1.125 & .51 \\
3.50 & .34 & 7.400 & .48 \\
3.99 & .49 & 1.105 & .49 \\
4.60 & .61 & 1.505 & .54 \\
5.21 & .61 & 1.530 & .55 \\
5.89 & .68 & 1.665 & .54 \\
6.28 & .39 & 0.900 & .50 \\
6.76 & .48 & 1.130 & .52 \\
7.06 & .30 & .810 & .59 \\
\hline
\end{tabular}

Total water equivalent $=3.48$ meters

Average density $=0.492$ 
Table 6. Stake and late season core measurements at South Cascade Glacier in the 1997 balance year

[Surface material is snow (s) or ice (i); density estimate based on measurement made in early May with seasonal adjustments. Depth and balance reflect the gain or loss of material, referenced to the previous year's melt horizon, in meters of water for balance. Local X and Y coordinates (in meters) given for each stake. Surface altitude (Z), in meters above National Geodetic Vertical Datum of 1929. 1997 stake and core locations shown on fig. 1]

\begin{tabular}{|c|c|c|c|c|}
\hline Date & $\begin{array}{l}\text { Surface } \\
\text { material }\end{array}$ & $\begin{array}{c}\text { Depth } \\
\text { (meters) }\end{array}$ & Density & $\begin{array}{l}\text { Balance } \\
\text { (meters) }\end{array}$ \\
\hline
\end{tabular}

\begin{tabular}{|c|c|c|c|c|}
\hline Date & $\begin{array}{l}\text { Surface } \\
\text { material }\end{array}$ & $\begin{array}{c}\text { Depth } \\
\text { (meters) }\end{array}$ & Density & $\begin{array}{l}\text { Balance } \\
\text { (meters) }\end{array}$ \\
\hline
\end{tabular}

\begin{tabular}{lcccc} 
Stake 2 & {$[\mathrm{X}=1915, \mathrm{Y}=2882, \mathrm{Z}=1836]$} \\
\hline May 9 & $\mathrm{s}$ & 6.81 & 0.49 & 3.34 \\
June 8 & $\mathrm{s}$ & 5.33 & .52 & 2.77 \\
Aug. 5 & $\mathrm{s}$ & 2.52 & .56 & 1.41 \\
Sept. 20 & $\mathrm{s}$ & .35 & .58 & .20 \\
Nov. 4 & $\mathrm{i}$ & -.10 & .90 & -.09 \\
\hline
\end{tabular}

\begin{tabular}{lcccc} 
Stake 5 & {$[\mathrm{X}=1717, \mathrm{Y}=3498, \mathrm{Z}=1681]$} \\
\hline May 9 & $\mathrm{s}$ & 4.60 & 0.51 & 2.35 \\
June 8 & $\mathrm{s}$ & 3.10 & .54 & 1.67 \\
Aug. 5 & $\mathrm{i}$ & -.52 & .90 & -.47 \\
Sept. 20 & $\mathrm{i}$ & -3.52 & .90 & -3.17 \\
Nov. 4 & $\mathrm{i}$ & -4.17 & .90 & -3.75 \\
\hline
\end{tabular}

Stake $3 \quad[X=1692, Y=3323, Z=1728]$

\begin{tabular}{lcccc}
\hline August 5 & $\mathrm{S}$ & 1.20 & 0.52 & 0.62 \\
Sept. 20 & $\mathrm{i}$ & -1.40 & .90 & -1.26 \\
Nov. 4 & $\mathrm{i}$ & -1.86 & .90 & -1.67 \\
Mimimum & $\mathrm{i}$ & & & \\
\hline \multicolumn{5}{l}{} \\
Stake 4 & {$[\mathrm{X}=1836, \mathrm{Y}=3584, \mathrm{Z}=1638]$} \\
\hline May 9 & $\mathrm{S}$ & 4.00 & 0.51 & 2.04 \\
June 8 & $\mathrm{S}$ & 2.60 & .54 & 1.40 \\
Aug 5. & $\mathrm{i}$ & -1.20 & .90 & -1.08 \\
Sept 20. & $\mathrm{i}$ & -4.10 & .90 & -3.69 \\
Nov. 4 & $\mathrm{i}$ & -4.85 & .90 & -4.37 \\
\hline
\end{tabular}

\begin{tabular}{lllll} 
Core $[X=2427, Y=1769, Z=2030]$ \\
\hline Sept. 20 & S & 3.80 & & \\
Minimum & S & 3.45 & 0.60 & 2.07 \\
\hline
\end{tabular}

Core $[X=2207, Y=1996, Z=1954]$

\begin{tabular}{lcccc}
\hline Sept. 20 & $\mathrm{~S}$ & 2.07 & & \\
Minimum & $\mathrm{S}$ & 1.67 & 0.60 & 1.00 \\
\hline \multicolumn{6}{c}{} \\
Core $[\mathrm{X}=2112, \mathrm{Y}=2210, \mathrm{Z}=1934]$ \\
\hline Sept. 20 & $\mathrm{~s}$ & 1.77 & \\
Minimum & $\mathrm{S}$ & 1.37 & 0.60 & 0.82 \\
\hline
\end{tabular}

\begin{tabular}{lcccc} 
Core $[X=1969, Y=2565, Z=1860]$ & \\
\hline Sept. 20 & s & 0.73 & & \\
Minimum & s & .31 & 0.60 & 0.19 \\
\hline
\end{tabular}


Table 7. South Cascade Glacier altitude grid, September 23, 1997

[Surface altitude (Z), in meters above National Geodetic Vertical Datum of 1929, was measured near the central point for each grid cell. Coordinates $\mathrm{X}$ and $\mathrm{Y}$ are local. $\mathrm{Z}$ is accurate to \pm 2 meters]

\begin{tabular}{|c|c|c|c|c|c|c|c|c|c|c|c|}
\hline$X$ & $Y$ & $Z$ & $X$ & $\mathrm{Y}$ & $Z$ & $\mathrm{X}$ & $\mathrm{Y}$ & $Z$ & $X$ & $Y$ & $Z$ \\
\hline 2270 & 1400 & 2078 & 2870 & 1802 & 2078 & 1868 & 2400 & 1895 & 1870 & 2900 & 1842 \\
\hline 2570 & 1400 & 2058 & 2271 & 1802 & 2008 & 2069 & 2401 & 1914 & 2370 & 2900 & 1840 \\
\hline 2470 & 1400 & 2060 & 2173 & 1896 & 1974 & 2270 & 2401 & 1930 & 1770 & 2900 & 1841 \\
\hline 2368 & 1401 & 2066 & 1969 & 1898 & 1971 & 1769 & 2401 & 1893 & 1671 & 2900 & 1841 \\
\hline 2671 & 1401 & 2091 & 2071 & 1901 & 1972 & 1971 & 2403 & 1907 & 2170 & 2999 & 1829 \\
\hline 2769 & 1401 & 2109 & 1869 & 1899 & 1990 & 2070 & 2499 & 1893 & 2269 & 2999 & 1828 \\
\hline 2272 & 1497 & 2042 & 2271 & 1901 & 1986 & 1769 & 2500 & 1882 & 1871 & 3000 & 1837 \\
\hline 2372 & 1499 & 2040 & 2370 & 1901 & 1991 & 2370 & 2500 & 1926 & 1970 & 3000 & 1837 \\
\hline 2470 & 1500 & 2047 & 2470 & 1900 & 2009 & 1471 & 2500 & 1900 & 1670 & 3000 & 1826 \\
\hline 2570 & 1500 & 2051 & 2171 & 1999 & 1957 & 1570 & 2500 & 1881 & 1770 & 3000 & 1831 \\
\hline 2170 & 1500 & 2048 & 1971 & 2000 & 1958 & 1669 & 2500 & 1883 & 2070 & 3001 & 1834 \\
\hline 2669 & 1504 & 2065 & 2469 & 2000 & 1985 & 2171 & 2500 & 1899 & 1469 & 3001 & 1833 \\
\hline 2770 & 1500 & 2078 & 1869 & 2001 & 1966 & 2270 & 2500 & 1912 & 1570 & 3001 & 1826 \\
\hline 2870 & 1500 & 2102 & 2070 & 2001 & 1958 & 1970 & 2500 & 1879 & 1670 & 3099 & 1807 \\
\hline 2269 & 1598 & 2022 & 2270 & 2001 & 1958 & 1869 & 2501 & 1881 & 2271 & 3100 & 1791 \\
\hline 3070 & 1600 & 2124 & 2368 & 2001 & 1966 & 2369 & 2599 & 1901 & 1870 & 3100 & 1824 \\
\hline 2170 & 1600 & 2019 & 2171 & 2100 & 1947 & 1570 & 2599 & 1865 & 1770 & 3100 & 1815 \\
\hline 2770 & 1601 & 2069 & 1969 & 2100 & 1946 & 1770 & 2599 & 1867 & 2170 & 3100 & 1812 \\
\hline 2870 & 1601 & 2082 & 2369 & 2100 & 1960 & 1970 & 2600 & 1860 & 1570 & 3100 & 1805 \\
\hline 2072 & 1601 & 2029 & 2269 & 2101 & $1953^{\circ}$ & 2170 & 2600 & 1874 & 2071 & 3100 & 1821 \\
\hline 2369 & 1601 & 2033 & 1771 & 2101 & 1943 & 2269 & 2600 & 1891 & 1971 & 3100 & 1825 \\
\hline 2669 & 1601 & 2058 & 2468 & 2101 & 1971 & 1670 & 2600 & 1867 & 1470 & 3101 & 1809 \\
\hline 2471 & 1601 & 2036 & 2571 & 2101 & 2005 & 1870 & 2601 & 1863 & 1670 & 3200 & 1778 \\
\hline 2569 & 1601 & 2046 & 2069 & 2101 & 1947 & 2070 & 2601 & 1860 & 1470 & 3200 & 1776 \\
\hline 2968 & 1602 & 2098 & 1870 & 2101 & 1942 & 2170 & 2699 & 1845 & 2170 & 3200 & 1770 \\
\hline 2271 & 1699 & 2012 & 2068 & 2199 & 1938 & 2370 & 2700 & 1871 & 1771 & 3201 & 1787 \\
\hline 2871 & 1699 & 2077 & 1669 & 2199 & 1930 & 1571 & 2700 & 1859 & 2069 & 3201 & 1775 \\
\hline 2769 & 1700 & 2068 & 2469 & 2199 & 1962 & 1970 & 2700 & 1851 & 1570 & 3201 & 1774 \\
\hline 2568 & 1700 & 2040 & 1869 & 2199 & 1920 & 2271 & 2700 & 1857 & 1870 & 3201 & 1796 \\
\hline 3168 & 1701 & 2123 & 2271 & 2199 & 1949 & 1870 & 2700 & 1854 & 1970 & 3201 & 1797 \\
\hline 2469 & 1701 & 2035 & 2170 & 2199 & 1943 & 1670 & 2701 & 1857 & 2170 & 3300 & 1725 \\
\hline 2669 & 1701 & 2054 & 1771 & 2200 & 1926 & 1770 & 2701 & 1856 & 1570 & 3300 & 1743 \\
\hline 2070 & 1701 & 1997 & 1970 & 2200 & 1933 & 1470 & 2701 & 1871 & 1970 & 3300 & 1734 \\
\hline 2169 & 1701 & 2006 & 2369 & 2201 & 1955 & 2070 & 2701 & 1848 & 1770 & 3300 & 1733 \\
\hline 2969 & 1701 & 2084 & 2068 & 2295 & 1928 & 1570 & 2799 & 1849 & 1670 & 3300 & 1742 \\
\hline 2370 & 1701 & 2025 & 2269 & 2299 & 1940 & 2270 & 2799 & 1838 & 2071 & 3301 & 1732 \\
\hline 1971 & 1702 & 2012 & 2369 & 2299 & 1943 & 2071 & 2799 & 1843 & 1471 & 3301 & 1750 \\
\hline 3069 & 1702 & 2105 & 1771 & 2300 & 1906 & 2170 & 2800 & 1835 & 1670 & 3399 & 1715 \\
\hline 3170 & 1795 & 2093 & 2170 & 2300 & 1932 & 1771 & 2800 & 1851 & 1871 & 3400 & 1672 \\
\hline 3071 & 1798 & 2084 & 2570 & 2300 & 2006 & 1670 & 2800 & 1850 & 2070 & 3400 & 1695 \\
\hline 1866 & 1799 & 2006 & 1971 & 2300 & 1922 & 1971 & 2800 & 1846 & 1570 & 3401 & 1714 \\
\hline 2370 & 1800 & 2016 & 1571 & 2301 & 1929 & 1870 & 2801 & 1848 & 1770 & 3401 & 1699 \\
\hline 2170 & 1800 & 1990 & 1671 & 2301 & 1908 & 1470 & 2801 & 1862 & 1670 & 3499 & 1685 \\
\hline 2770 & 1800 & 2068 & 1870 & 2301 & 1909 & 2370 & 2801 & 1854 & 1869 & 3500 & 1649 \\
\hline 2472 & 1800 & 2029 & 2470 & 2301 & 1957 & 1569 & 2899 & 1842 & 1570 & 3500 & 1679 \\
\hline 2072 & 1800 & 1983 & 2369 & 2399 & 1940 & 1969 & 2899 & 1843 & 1770 & 3500 & 1672 \\
\hline 1970 & 1800 & 1991 & 2469 & 2399 & 1959 & 2169 & 2899 & 1836 & 1670 & 3600 & 1655 \\
\hline 2670 & 1801 & 2053 & 2170 & 2400 & 1916 & 2270 & 2899 & 1830 & 1769 & 3601 & 1650 \\
\hline 2970 & 1801 & 2080 & 1670 & 2400 & 1893 & 1469 & 2900 & 1848 & & & \\
\hline 2571 & 1801 & 2036 & 1569 & 2400 & 1900 & 2070 & 2900 & 1839 & & & \\
\hline
\end{tabular}


Table 8. Precipitation (gage catch) at 1,587 meters altitude, Salix Creek gaging station, 1997 water year

[Precipitation is summed every hour and the daily sum is given in millimeters.

A -99.0 indicates no data]

\begin{tabular}{|c|c|c|c|c|c|c|c|c|c|c|c|c|}
\hline DAY & Oct. & Nov. & Dec. & Jan. & Feb. & Mar. & Apr. & May & June & July & Aug. & Sept. \\
\hline 1 & 0.0 & 0.0 & 0.0 & 11.9 & 0.0 & 0.0 & 2.3 & -99.0 & -99.0 & 2.8 & 0.0 & 0.3 \\
\hline 2 & 0.0 & 0.0 & 0.0 & 0.3 & 0.0 & 0.0 & 3.1 & -99.0 & -99.0 & 0.3 & 0.0 & 0.0 \\
\hline 3 & 10.2 & 0.0 & 0.0 & 0.0 & 0.0 & 0.0 & 0.0 & -99.0 & -99.0 & 0.0 & 0.0 & 9.4 \\
\hline 4 & 37.3 & 0.0 & 0.0 & 0.0 & 0.0 & 0.0 & 4.6 & -99.0 & -99.0 & 0.0 & 0.0 & 0.0 \\
\hline 5 & 2.8 & 0.0 & 0.0 & 0.0 & 0.0 & 0.0 & 3.3 & -99.0 & -99.0 & 4.3 & 0.0 & 2.8 \\
\hline 6 & 0.0 & 0.0 & 0.0 & 0.0 & 0.0 & 0.0 & 0.0 & -99.0 & -99.0 & 9.1 & -99.0 & 0.0 \\
\hline 7 & 0.0 & 0.0 & 0.0 & 0.0 & 0.0 & 0.0 & 0.0 & -99.0 & -99.0 & 0.0 & -99.0 & 0.0 \\
\hline 8 & 0.0 & 43.2 & 0.0 & 0.0 & 0.0 & 0.0 & 0.0 & -99.0 & 0.0 & 40.1 & -99.0 & 0.0 \\
\hline 9 & 0.0 & 0.0 & 0.0 & 0.0 & 0.0 & 0.0 & 0.0 & -99.0 & 0.0 & 41.9 & -99.0 & 0.0 \\
\hline 10 & 0.3 & 0.0 & 0.0 & 0.0 & 0.3 & 0.0 & 0.5 & -99.0 & 0.0 & 12.4 & -99.0 & 0.0 \\
\hline 11 & 11.2 & 0.0 & 0.0 & 0.0 & 0.0 & 0.0 & 0.0 & -99.0 & 0.0 & 6.3 & 0.0 & 9.2 \\
\hline 12 & 3.3 & 15.2 & 0.0 & 0.0 & 0.0 & 0.0 & 0.0 & -99.0 & 18.5 & 0.8 & 0.0 & 7.9 \\
\hline 13 & 23.9 & 8.6 & 0.0 & 0.0 & 0.0 & 0.0 & 0.0 & -99.0 & 0.0 & 0.0 & 0.0 & 10.9 \\
\hline 14 & 20.6 & 0.0 & 0.0 & 0.0 & 0.0 & 0.0 & 8.9 & -99.0 & 0.0 & 0.0 & 0.0 & 16.8 \\
\hline 15 & 0.0 & 0.0 & 0.0 & 0.0 & 19.3 & 0.0 & 16.8 & -99.0 & 0.0 & 0.0 & 0.0 & 16.2 \\
\hline 16 & 0.0 & 0.0 & 0.0 & 0.0 & 7.6 & 0.3 & 6.1 & -99.0 & 1.8 & 0.0 & 0.0 & 32.0 \\
\hline 17 & 0.0 & 0.0 & 0.0 & 19.3 & 1.0 & 0.0 & 0.3 & -99.0 & 53.4 & 0.0 & 0.0 & 36.8 \\
\hline 18 & 0.0 & 0.0 & 3.3 & 34.0 & 0.0 & 56.7 & 0.5 & -99.0 & 17.5 & 0.0 & 0.0 & 18.3 \\
\hline 19 & 0.0 & 0.0 & 0.0 & 25.9 & 0.0 & 83.6 & 18.5 & -99.0 & 4.1 & 0.0 & 0.0 & 0.0 \\
\hline 20 & 0.0 & 0.0 & 0.0 & 4.3 & 0.0 & 6.1 & 0.0 & -99.0 & 0.8 & 0.0 & 4.3 & 0.0 \\
\hline 21 & 38.8 & 0.0 & 0.0 & 0.0 & 0.0 & 0.0 & 6.4 & -99.0 & 15.2 & 0.0 & 0.8 & 0.0 \\
\hline 22 & 15.8 & 0.0 & 0.0 & 0.0 & 0.0 & 5.4 & 0.3 & -99.0 & 9.4 & 9.4 & 0.0 & 0.0 \\
\hline 23 & 2.5 & 0.0 & 0.0 & 0.0 & 6.4 & 0.0 & 7.1 & -99.0 & 11.2 & 0.0 & 1.3 & 0.0 \\
\hline 24 & 1.0 & 0.0 & 0.0 & 0.0 & 10.9 & 3.1 & 6.1 & -99.0 & 0.8 & 0.0 & 4.1 & 0.0 \\
\hline 25 & 0.3 & 0.0 & 0.0 & 0.0 & 2.0 & 4.0 & -99.0 & -99.0 & 5.1 & 0.0 & 6.1 & 11.9 \\
\hline 26 & 0.0 & 0.0 & 0.0 & 0.0 & 0.0 & 12.0 & -99.0 & -99.0 & 3.3 & 0.0 & 17.8 & 42.7 \\
\hline 27 & 18.0 & 62.5 & 0.0 & 0.0 & 0.0 & 0.0 & -99.0 & -99.0 & 0.5 & 0.0 & 2.5 & 36.6 \\
\hline 28 & 51.3 & 5.8 & 0.0 & 0.3 & 0.0 & 0.0 & -99.0 & -99.0 & 0.0 & 0.0 & 8.4 & 9.2 \\
\hline 29 & 0.5 & 0.0 & 0.3 & 10.4 & & 4.3 & -99.0 & 99.0 & 21.6 & 0.8 & 1.5 & 0.0 \\
\hline 30 & 0.0 & 6.1 & 17.0 & 81.5 & & 2.5 & -99.0 & -99.0 & 0.3 & 2.0 & 0.0 & 11.2 \\
\hline 31 & 0.0 & & 9.2 & 0.5 & & 0.0 & & -99.0 & & 0.0 & 0.5 & \\
\hline SUM & 237.7 & 141.5 & 29.7 & 188.4 & 47.5 & 177.8 & - & - & $\cdots$ & 130.2 &.- & 272.0 \\
\hline
\end{tabular}




\begin{tabular}{|c|c|c|c|c|c|}
\hline 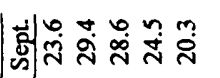 & 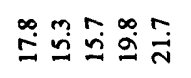 & 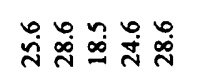 & 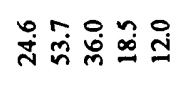 & 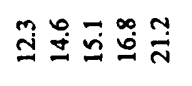 & 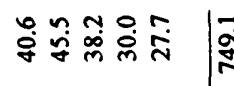 \\
\hline âd & 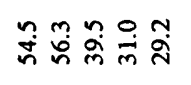 & 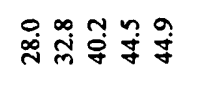 & 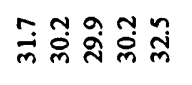 & 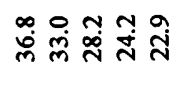 & \\
\hline 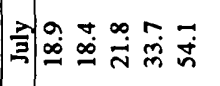 & 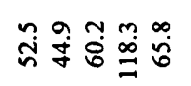 & 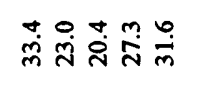 & 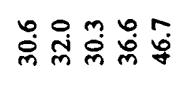 & 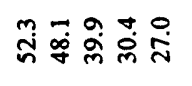 & 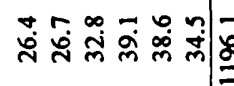 \\
\hline 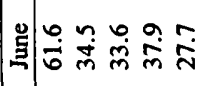 & 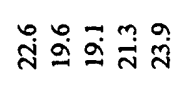 & 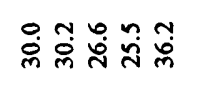 & 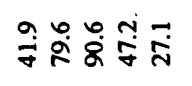 & 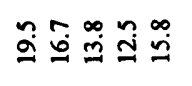 & 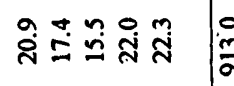 \\
\hline 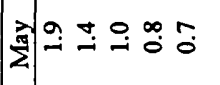 & $\stackrel{\infty}{\infty} \stackrel{\infty}{0} \stackrel{\infty}{0} \tilde{i}$ & 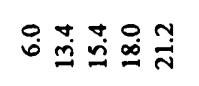 & 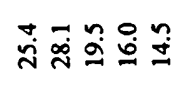 & 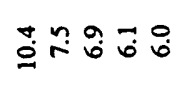 & $\overline{6} 00$. \\
\hline 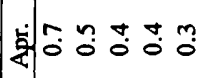 & ํㅗㅇ 공 $\overline{0}: \overrightarrow{0}$ & $\overrightarrow{0}: 0 \overrightarrow{0} \overline{0}=\overrightarrow{0}$ & 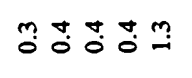 & 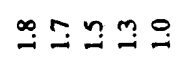 & 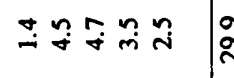 \\
\hline 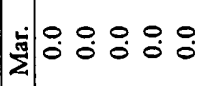 & 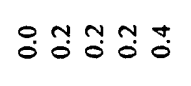 & $\ddot{0}: \overrightarrow{0} \overrightarrow{0} \overrightarrow{0} \overrightarrow{0}$ & 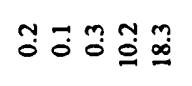 & श्वे & 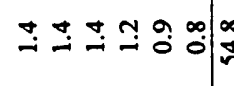 \\
\hline 过 & 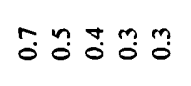 & 공 mo mo mo & 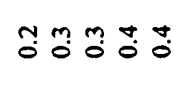 & 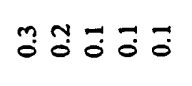 & $\because \ddot{0} \div 0$ \\
\hline$\pm=$ & 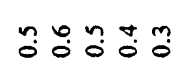 & 궁 $\overrightarrow{0} \overrightarrow{0}: \overrightarrow{0}$ & 영 范 & & $\therefore 3$ \\
\hline 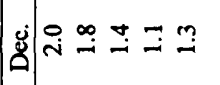 & $\exists \stackrel{\text { I }}{\circ} \stackrel{0}{-} \stackrel{\infty}{\circ} \stackrel{0}{\circ}$ & 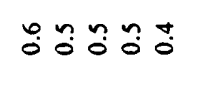 & 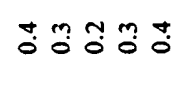 & & $\tilde{s}: \tilde{o}$ \\
\hline$\vec{z}$ & 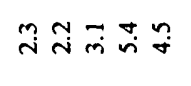 & 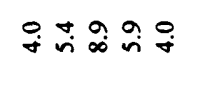 & 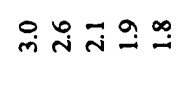 & $\simeq$ & 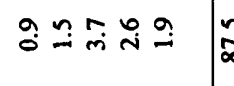 \\
\hline 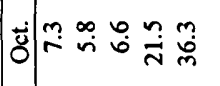 & $\stackrel{\circ}{\Xi} \stackrel{\circ}{\dot{I}} \stackrel{\varrho}{=} \stackrel{\infty}{=}$ & 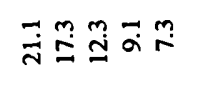 & 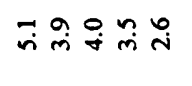 & & \\
\hline$-N m+n$ & & $=\simeq \underline{2}$ & $\simeq=$ & & \\
\hline
\end{tabular}

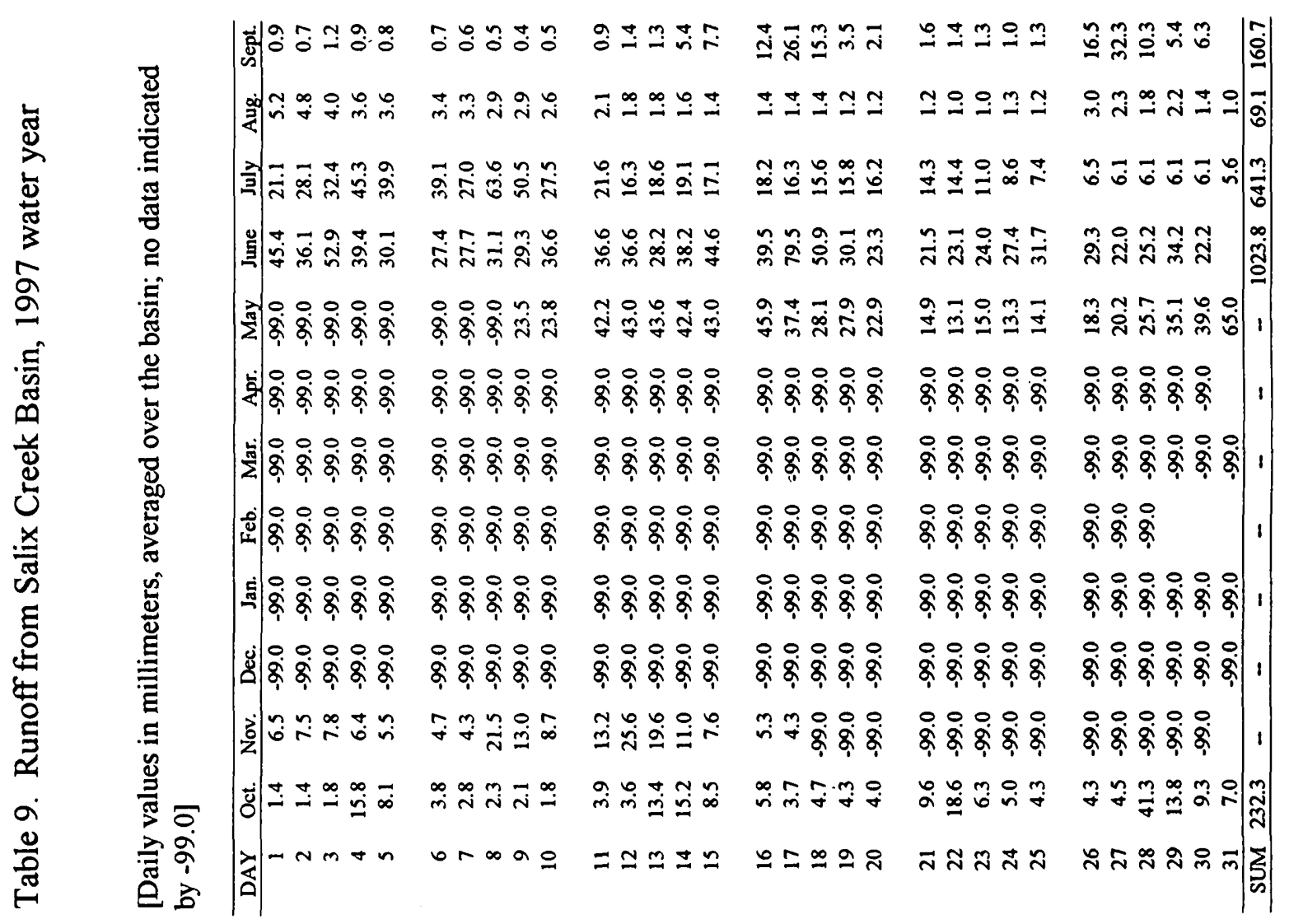


Table 11. Runoff from Middle Tarn Basin, 1997 water year

[Daily values in millimeters, averaged over the basin. A -99.0 indicates no data]

\begin{tabular}{|c|c|c|c|c|c|c|c|c|c|c|c|c|}
\hline DAY & Oct. & Nov. & Dec. & Jan. & Feb. & Mar. & Apr. & May & June & July & Aug. & Sept. \\
\hline 1 & 8.0 & 2.3 & 3.6 & -99.0 & -99.0 & -99.0 & -99.0 & -99.0 & -99.0 & -99.0 & -99.0 & 27.9 \\
\hline 2 & 6.7 & 2.2 & 3.8 & -99.0 & -99.0 & -99.0 & -99.0 & -99.0 & -99.0 & -99.0 & -99.0 & 31.1 \\
\hline 3 & 12.2 & 2.0 & 3.8 & -99.0 & -99.0 & -99.0 & -99.0 & -99.0 & -99.0 & -99.0 & -99.0 & 26.8 \\
\hline 4 & 34.2 & 1.8 & 3.8 & -99.0 & -99.0 & -99.0 & -99.0 & -99.0 & -99.0 & -99.0 & 9.0 & 23.2 \\
\hline 5 & 25.6 & 1.5 & 3.8 & -99.0 & -99.0 & -99.0 & -99.0 & -99.0 & -99.0 & -99.0 & -99.0 & 19.8 \\
\hline 6 & 14.5 & 1.8 & 3.8 & -99.0 & -99.0 & -99.0 & -99.0 & -99.0 & -99.0 & -99.0 & 56.8 & 17.8 \\
\hline 7 & 16.9 & 1.3 & 3.8 & -99.0 & -99.0 & -99.0 & -99.0 & -99.0 & -99.0 & -99.0 & 43.0 & 16.5 \\
\hline 8 & 12.3 & 4.4 & 3.7 & -99.0 & -99.0 & -99.0 & -99.0 & -99.0 & -99.0 & -99.0 & 32.4 & 19.8 \\
\hline 9 & 16.5 & 5.4 & 3.4 & -99.0 & -99.0 & -99.0 & -99.0 & -99.0 & -99.0 & -99.0 & 29.0 & 23.2 \\
\hline 10 & 16.6 & 3.4 & 3.4 & -99.0 & -99.0 & -99.0 & -99.0 & -99.0 & -99.0 & -99.0 & 27.8 & 22.7 \\
\hline 11 & 26.9 & 3.4 & 3.3 & -99.0 & -99.0 & -99.0 & -99.0 & -99.0 & -99.0 & -99.0 & 28.9 & 30.2 \\
\hline 12 & 13.9 & 6.1 & 3.1 & -99.0 & -99.0 & -99.0 & -99.0 & -99.0 & -99.0 & -99.0 & 35.7 & 23.8 \\
\hline 13 & 9.9 & 6.4 & 3.1 & -99.0 & -99.0 & -99.0 & -99.0 & -99.0 & -99.0 & -99.0 & 38.9 & 16.5 \\
\hline 14 & 6.9 & 3.8 & 3.1 & -99.0 & -99.0 & -99.0 & -99.0 & -99.0 & -99.0 & -99.0 & 43.1 & 27.5 \\
\hline 15 & 5.1 & 2.8 & 3.1 & -99.0 & -99.0 & -99.0 & -99.0 & -99.0 & -99.0 & -99.0 & 35.1 & 24.3 \\
\hline 16 & 3.9 & 2.3 & 3.1 & -99.0 & -99.0 & -99.0 & -99.0 & -99.0 & -99.0 & -99.0 & 28.5 & 24.1 \\
\hline 17 & 2.9 & 2.7 & 2.9 & -99.0 & -99.0 & -99.0 & -99.0 & -99.0 & -99.0 & -99.0 & 29.0 & 42.8 \\
\hline 18 & 3.0 & 2.2 & 2.6 & -99.0 & -99.0 & -99.0 & -99.0 & -99.0 & -99.0 & -99.0 & 29.2 & 20.1 \\
\hline 19 & 2.4 & 4.9 & 2.5 & -99.0 & -99.0 & -99.0 & -99.0 & -99.0 & -99.0 & -99.0 & 29.8 & 11.5 \\
\hline 20 & 2.0 & 6.8 & 2.5 & -99.0 & -99.0 & -99.0 & -99.0 & -99.0 & -99.0 & -99.0 & 33.0 & 11.1 \\
\hline 2 & 2.3 & 6.6 & 2.5 & -99.0 & -99.0 & -99.0 & -99.0 & -99.0 & -99.0 & -99 & 36.2 & 14.3 \\
\hline 22 & 3.1 & 6.2 & 2.5 & -99.0 & -99.0 & -99.0 & -99.0 & -99.0 & -99.0 & -99.0 & 28.8 & 15.6 \\
\hline 23 & 2.0 & 6.1 & 99.0 & -99.0 & -99.0 & -99.0 & -99.0 & -99.0 & -99.0 & -99.0 & 26.1 & 15.7 \\
\hline 24 & 1.6 & 5.1 & -99.0 & -99.0 & -99.0 & -99.0 & -99.0 & -99.0 & -99.0 & -99.0 & 22.9 & 19.1 \\
\hline 25 & 1.3 & 4.2 & -99.0 & -99.0 & -99.0 & -99.0 & -99.0 & -99.0 & -99.0 & -99.0 & 24.2 & 24.2 \\
\hline 26 & 1.2 & 4.1 & -99.0 & -99.0 & -99.0 & -99.0 & -99.0 & -99.0 & -99.0 & -99.0 & 34.6 & 37.0 \\
\hline 27 & 1.0 & 2.8 & -99.0 & -99.0 & -99.0 & -99.0 & -99.0 & -99.0 & -99.0 & -99.0 & 32.6 & 28.5 \\
\hline 28 & 12.4 & 2.4 & -99.0 & -99.0 & -99.0 & -99.0 & -99.0 & -99.0 & -99.0 & -99.0 & 22.1 & 34.1 \\
\hline 29 & 6.8 & 1.0 & -99.0 & -99.0 & & -99.0 & -99.0 & -99.0 & -99.0 & -99.0 & 23.3 & 18.8 \\
\hline 30 & 4.1 & 0.8 & -99.0 & -99.0 & & -99.0 & -99.0 & -99.0 & -99.0 & -99.0 & 21.3 & 32.6 \\
\hline 31 & 2.7 & & -99.0 & -99.0 & & -99.0 & & -99.0 & & -99.0 & 22.1 & \\
\hline SUM & 279.1 & 106.4 & -- & -- & -- & -- & -- & -- & -- & -- & -- & 700.5 \\
\hline
\end{tabular}


Table 12. Values used to interpolate snow depth at any altitude on South Cascade Glacier, 1997 [values in meters]

\begin{tabular}{cc}
\hline Altitude & Snow depth \\
\hline 1581 & 1.6 \\
1607 & 2.4 \\
1619 & 2.9 \\
1644 & 3.6 \\
1675 & 4.3 \\
1710 & 5.0 \\
1743 & 5.6 \\
1784 & 6.3 \\
1827 & 6.9 \\
1873 & 7.5 \\
1920 & 8.1 \\
1968 & 8.7 \\
2016 & 9.2 \\
2069 & 9.8 \\
2120 & 10.4 \\
2168 & 10.9 \\
\hline
\end{tabular}

Table 13. Values used to interpolate net balance at any altitude on South Cascade Glacier, 1997 [values in meters]

\begin{tabular}{cc}
\hline Altitude & Net balance \\
\hline 1627 & -5.33 \\
1642 & -4.52 \\
1664 & -3.74 \\
1687 & -2.99 \\
1714 & -2.23 \\
1746 & -1.51 \\
1786 & -.81 \\
1830 & -.17 \\
1883 & .46 \\
1934 & 1.06 \\
1992 & 1.63 \\
2051 & 2.15 \\
2093 & 2.54 \\
2141 & 2.94 \\
\hline
\end{tabular}


TABLE 14. Mass balance time series at South Cascade Glacier

[For years 1986-91, net balance, $\bar{b}_{\mathrm{n}}$, was determined by the index regression method discussed in Krimmel (1989) and has an error of $0.23 \mathrm{~m}$. For years $1959-64$ and $1968-82$, winter balance, $\bar{b}_{\mathrm{m}}(\mathrm{s})$, was determined from unpublished snow accumulation maps and has an error of $0.12 \mathrm{~m}$. For years $1983-1991, \bar{b}_{\mathrm{m}}(\mathrm{s})$ was determined using the index station regression discussed in Krimmel (1989) and has an error of $0.23 \mathrm{~m}]$

\begin{tabular}{rcc||ccc}
\hline Year $^{1}$ & $\begin{array}{c}\bar{b}_{\mathrm{m}}(\mathrm{s}) \\
\text { (meters) }\end{array}$ & $\begin{array}{c}\bar{b}_{\mathrm{n}} \\
\text { (meters) }\end{array}$ & Year $^{1} \cdot$ & $\begin{array}{c}\bar{b}_{\mathrm{m}}(\mathrm{s}) \\
\text { (meters) }\end{array}$ & $\begin{array}{c}\bar{b}_{\mathrm{n}} \\
\text { (meters) }\end{array}$ \\
\hline${ }^{2} 1959$ & 3.28 & 0.70 & 1979 & 2.18 & -1.56 \\
1960 & 2.21 & -0.50 & 1980 & 1.83 & -1.02 \\
1961 & 2.40 & -1.10 & 1981 & 2.28 & -0.84 \\
1962 & 2.50 & 0.20 & 1982 & 3.11 & 0.08 \\
1963 & 2.23 & -1.30 & 1983 & 1.91 & -0.77 \\
1964 & 3.25 & 1.20 & 1984 & 2.38 & 0.12 \\
${ }^{3} 1965$ & 3.48 & -0.17 & 1985 & 2.18 & -1.20 \\
1966 & 2.47 & -1.03 & 1986 & 2.43 & -0.71 \\
${ }^{4} 1967$ & 3.29 & -0.63 & 1987 & 1.88 & -2.56 \\
${ }^{5} 1968$ & 3.00 & 0.01 & 1988 & 1.89 & -1.64 \\
1969 & 3.17 & -0.73 & 1989 & 2.35 & -0.71 \\
1970 & 2.41 & -1.20 & 1990 & 2.80 & -0.73 \\
1971 & 3.51 & 0.60 & 1991 & 3.35 & -0.20 \\
1972 & 4.27 & 1.43 & 1992 & 1.91 & -2.01 \\
1973 & 2.21 & -1.04 & 1993 & 1.98 & -1.23 \\
1974 & 3.65 & 1.02 & 1994 & 2.39 & -1.60 \\
1975 & 3.06 & -0.05 & 1995 & 2.81 & -0.69 \\
1976 & 3.53 & 0.95 & 1996 & 2.94 & 0.10 \\
1977 & 1.57 & -1.30 & 1997 & 3.71 & 0.63 \\
1978 & 2.49 & -0.38 & & & \\
\hline
\end{tabular}

1 Balance year (for example, 1959 is from the minimum balance in 1958 to the minimum balance in 1959 , and the $1959 \bar{b}_{\mathrm{m}}(\mathrm{s})$ occurred in the spring of 1959)

$2 \bar{b}_{\mathrm{n}}$ for years 1959 through 1964 from Meier and Tangborn (1965)

3 Years 1965 through 1966 from Meier and others (1971)

4 Year 1967 from Tangborn and others (1977)

$5 \bar{b}_{\mathrm{n}}$ for years 1968 through 1985 from Krimmel (1989) 


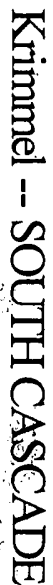

号

ซ్

ద

蛋

勇

I

突

$\infty$

용 